\title{
ÎNVĂȚÂND PRIN JOACĂ. \\ RECUPERAREA SPAȚIILOR EXTERIOARE ANEXATE UNITĂȚILOR DE ÎNVĂȚĂMÂNT
}

drd. arh. Diana Popa

Universitatea de Arhitectură și Urbanism „Ion Mincu” - Școala Doctorală de Arhitectură, București

gogoasa.diana.arh@gmail.com

\section{Rezumat}

Această lucrare pune sub lupă spațiile exterioare din jurul unităților de învățământ studiate prin prisma spectrului istoric, făcând referire la modul în care evoluează în funcție de factorii determinanți, de context şi de nevoile fiecărei perioade istorice. Studiul teoretic se concentrează pe amenajările tematice cu caracter educativ și pe modul în care spațiile de relaxare aferente învățământului capătă un rol foarte important în formarea tinerilor, devenind din ce în ce mai educative.

Tendința copiilor moderni de a sta cât mai mult în casă, pentru că „acolo sunt toate electronicele şi jocurile” (Louv, 2005, p. 9), a devenit o problemă din ce în ce mai discutată. Întrebarea la care studiul teoretic încearcă să răspundă este: „Cum reușim ca prin intermediul amenajărilor să stârnim interesul adolescenților de a petrece mai mult timp departe de monitoare?".

În primă instanță, lucrarea caută să urmărească, prin raportul dintre spaţiul interior şi cel exterior, necesitatea spațiilor verzi cu caracter educativ adiționale unităților de învățământ prin prisma istoriei. Se remarcă modul în care acestea au evoluat treptat, trecând de la spații închise, de tip curte interioară, care se potriveau perfect cerințelor funcționale și spiritului de claustrare specific societății evului mediu, la spații cu caracter tematic, definite prin integrarea sportului, ajungând în prezent la spații capabile să stimuleze creativitatea și intelectul copiilor prin implicarea lor pro-activă.

În partea a doua studiul se concentrează pe analizarea unui proiect internațional aparte al amenajărilor peisagere cu caracter tematic-educativ. Această investigație de detaliu contribuie la identificarea și explicitarea posibilităților de a privi mai comprehensiv relația interior-exterior. Proiectul ales drept studiu de caz a demonstrat în timp real capacitatea de a susține şi consolida funcţiunile interioare, prin transpunerea şi extinderea lor în spaţiul exterior şi de a stimula creativitatea şi capacitatea copiilor de a interaç̧iona cu cadrul natural.

Cuvinte cheie: recuperarea spațiilor exterioare, unități de învățământ, relația interior- exterior, arhitectură cu rol educativ 


\section{Scurt istoric privind relația interior - exterior din cadrul unităților de învățământ}

Multe studii se bazează pe cercetări amănunțite privind sănătatea omului. Majoritatea indică faptul că aceasta nu este influențată doar de echilibrul cu mediul, ci şi de raportul dintre activitate fizică sau intelectuală şi activitate recreativă. În alegerea formelor de relaxare şi a dotărilor specifice, interesant de urmărit sunt: timpul liber disponibil, dimensiunea sitului, preocupările şi înclinațiile utilizatorilor (Iliescu, 2003, p.101). În cadrul unităților de învățământ factorul temporal-recreativ este cunoscut, pauzele, însă un scurt istoric legat de evoluția spațiului ne ajută să înțelegem cum se utilizează un astfel de loc, precum şi modul în care necesitățile variază în funcție de perioada istorică.

Primele unități de învățământ organizat apar în Zona Eufratului (Ninive, Babilon) şi sunt destinate cu precădere formării scribilor ${ }^{1}$. Acestea încep să capete structură academică prin anexarea bibliotecilor, începând cu secolul XVIII-lea î.e.n.. Astfel, se poate vorbi de o schimbare majoră atât din punct de vedere peisagistic, cât şi arhitectural, de la camera necesară relației de îndrumător-elev la spații ample cu valențe multiple.

Egiptul Antic promovează pentru prima dată ideea de instrucție în colectiv, dar şi ideea de comuniune cu natura. Orele de studiu se desfășurau cu precădere în curțile palatelor sau în centrele de formație ${ }^{2}$. Deşi nu se poate vorbi de o vegetație abundentă în această zonă, grădinile, puţine la număr, devin oaze naturale în peisaje deșertice, fiind populate în general cu sicomori, curmali, rodii etc. Un alt aspect important, în grădinile egiptene, este dat de rectangularul bazin populat cu peşti coloraţi şi decorat cu lotuşi, tot peisajul fiind bine încadrat cu rânduri de arbori, demonstrând rafinamentul propriu al artei egiptene, dar şi nevoia unui contact cu natura în viaţa de zi cu zi.

În Grecia Antică educația copiilor este prezentată în două situații total diferite în Sparta şi Atena. Copilul spartan aparținea statului începând cu vârsta de 7 ani, iar educația se referea la antrenamente fizice dure, instrucția intelectuală fiind minimă. Apar spațiile destinate sportului ca şi elemente dominante în peisajul exterior școlii. În cealaltă extremă se aflau tinerii din Atena. Sistemul de învățământ se împărțea în două tipuri: școala gramaticului - unde activitatea de educație se împlinea în casa personală sau sub porticele orașului; iar cea de-a doua categorie: gimnaziul şi palestra - „fiecare oraș, oricât de mic, avea un teatru şi un gimnaziu" (Vais, 2008, p. 26).

În perioada elenistă, gimnaziul devenea unul dintre actorii principali din cadrul orașului, bucurându-se de o poziție centrală, deseori alipit agorei. În secolele V-IV î.e.n. s-au creat şi primele grădini proiectate pe lângă gimnazii şi academii. Acestea aveau dimensiuni relativ restrânse, cu trasee mai puţin riguroase şi cu numeroase elemente decorative: pergole, porticuri, fântâni, statui, alcătuind un cadru estetic întregit de vegetație (Iliescu, 2003, p. 101). Grădinile se dezvoltau ca şi spaţii de tip curte interioară cu deosebită valoare funcțională, în cadrul căreia se desfășurau activități educative, lucru ce demonstrează importanţa cadrului exterior în viaţa grecilor şi capacitatea lor de a integra natura în funcţiuni din cele mai diverse. În jurul acestui spațiu se dispuneau încăperi cu caracter strict educativ: biblioteci, săli de curs, băi (ablutio), ş.a. (Vais, 2008, p. 27). Ca şi studii de caz, cele mai interesante gimnazii şi palestre, sunt exemplele din Olimp (Fig. 1), Priene şi Milet (Fig. 2), unde se poate remarca proximitatea sau chiar contactul direct cu apa a spațiilor de învățământ.

\footnotetext{
${ }^{1}$ Funcţionari ai administraţiei şi templelor

2 temple
} 


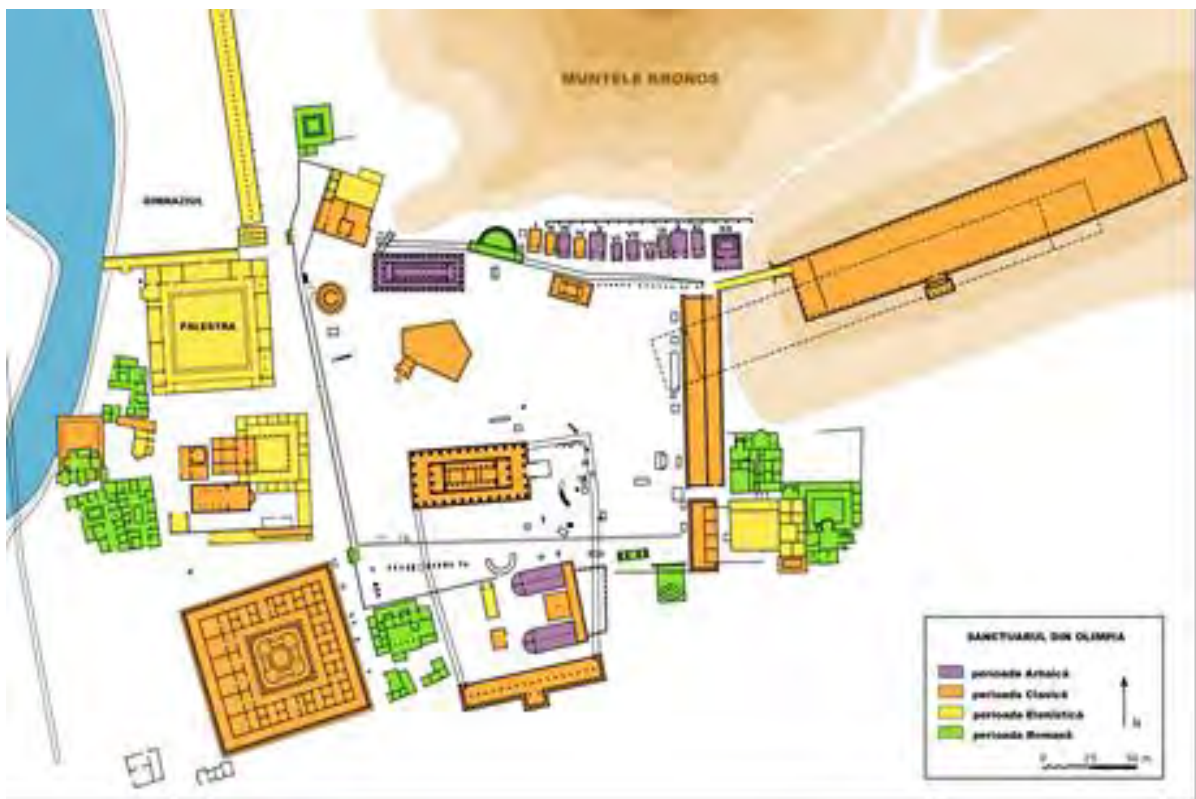

Fig. 1. Planul orașului Olimp cu evidenţierea gimnaziului şi palestrei Sursa: https://en.wikipedia.org/wiki/Olympia,_Greece, accesat 17.05.2018, imagine procesată de autor

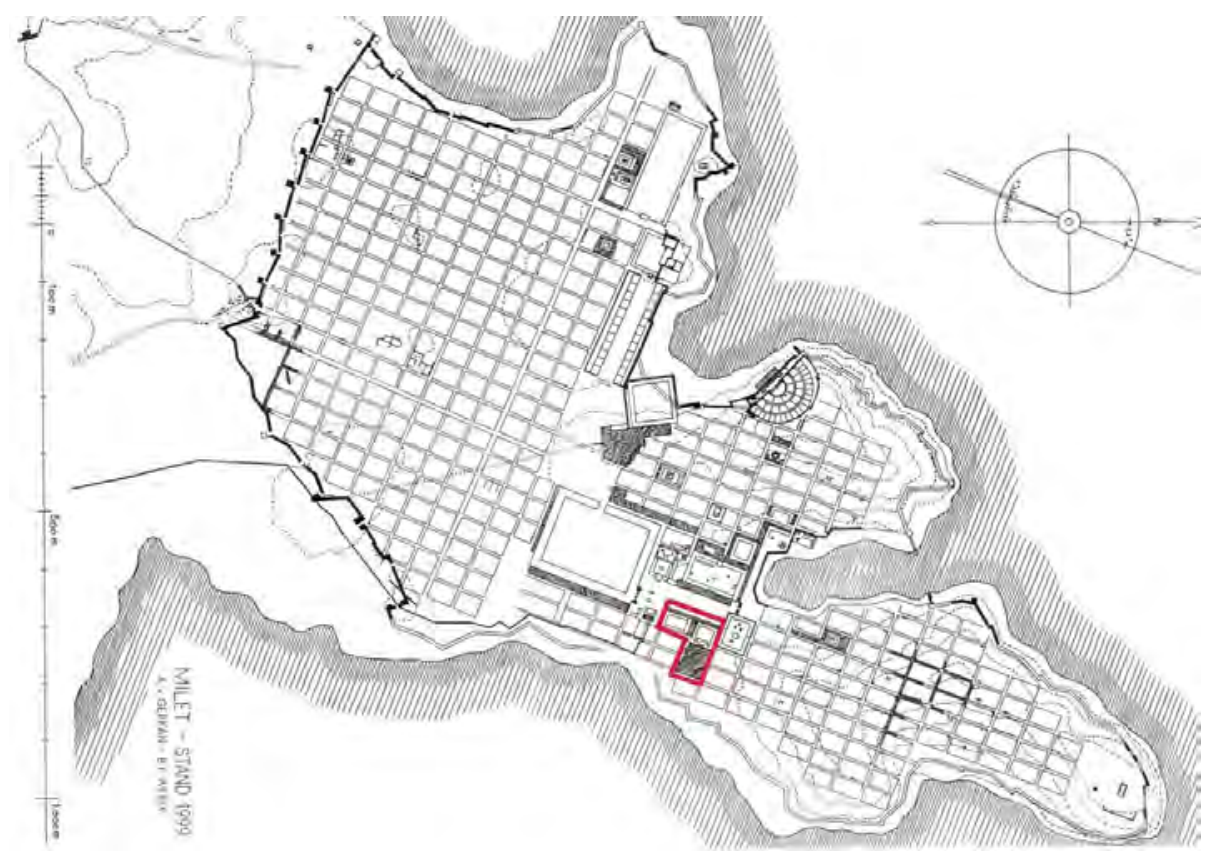

Fig. 2. Planul orașului Milet cu evidenţierea gimnaziului şi palestrei

Sursa: http://www.ruhr-uni-bochum.de/milet/in/stadt-plan/stadt-pl.jpg, accesat 17.05.2018, imagine procesată de autor

Grădinile filosofice sau grădinile publice sunt un răspuns al regimului democratic, specific epocii, care au adus un plus societății umane. Locurile de plimbare şi recreaţie, parcurile şi piscinele palastrelor şi gimnaziilor sunt publice şi localizate deseori în afara oraşului. Spre sfârşitul secolului al IV-lea î.e.n. putem vorbi de o evoluţie a învăţământului, dar şi a relației dintre interior-exterior. În cadrul acestor grădini, Platon şi Aristotel, aşa cum arată scrierile, îşi întemeiază academii. „Academia platonică își desfășura activitatea în grădinile lui Academism, plantate cu sălcioară, tisă, plopi cu frunze argintii, ulmi şi platani." (Vişoiu, 2001, p. 32)

Orientarea spre religie din Evul Mediu este cea care va domina învățământul, oferind tipul primar de învățământ colectiv, care va determina apariția spațiului educativ. Planul gimnaziului 
antic stă la baza construcțiilor de şcoli şi mai cu seamă. Curtea interioară se pliază perfect pe spiritul claustrofobic specific epocii. Ca martor al şcolii mânăstirești stă planul din manuscrisul Saint-Gall (Fig. 3), din jurul anului 818. Conceptul este un mixaj între castrul roman, transpus prin rigurozitate şi sistematizare şi principiul gimnaziului antic. Cu toate acestea, deşi spațiul de învățământ nu dispune de o curte proprie, se remarcă atenția sporită de care se bucurau grădinile, fiind atent proiectate.

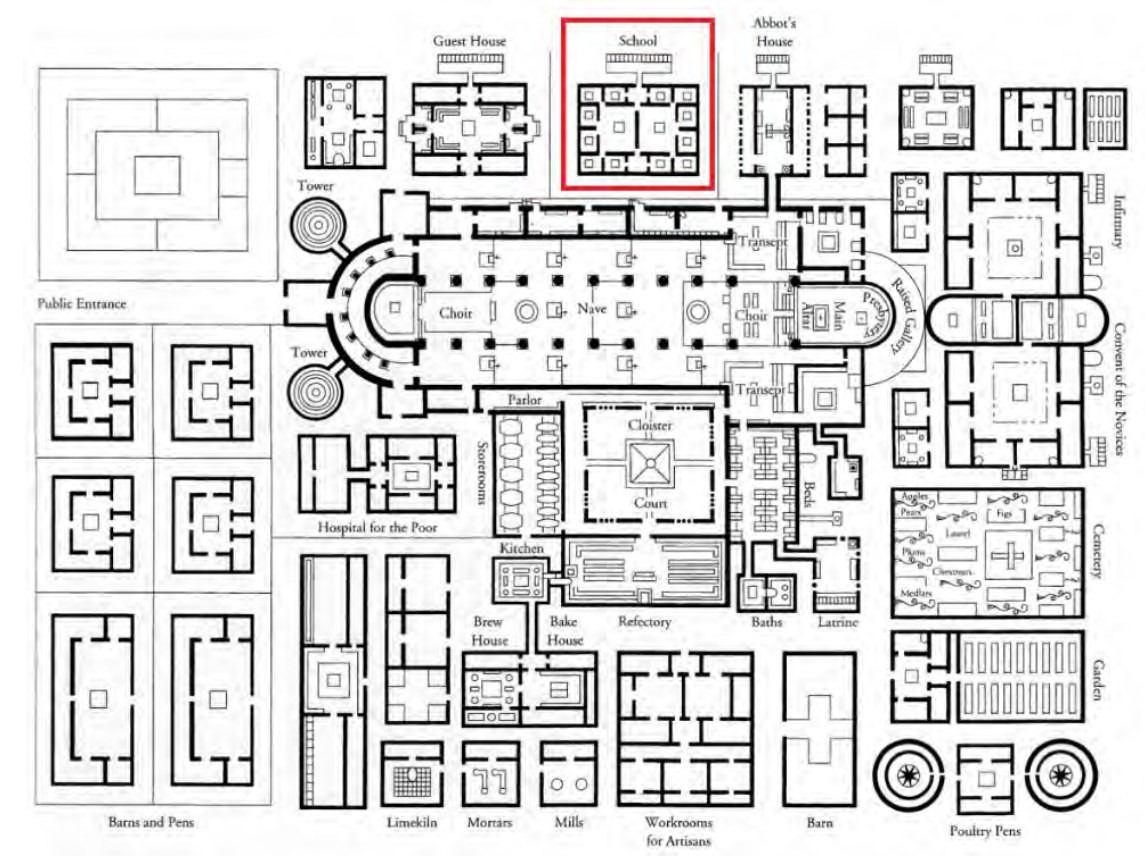

Fig. 3. Planul Mănăstirii Saint Gall, Elveția

Sursa: https://classconnection.s3.amazonaws.com/530/flashcards/2210530/png/screen_shot_2012-11-09_ at_112058_am1352486003686.png accesat 17.05.2018, imagine procesată de autor

Tipul de școală orășenească din aceasta perioadă, prezentă în general în cadrul locuințelor individuale, se remarcă printr-un element definitoriu de celelalte construcții, caracterizate prin izolare în raport cu mediul înconjurător ostil, claustrofobic, neutru şi distant față de natură, demonstrând caracterul privilegiat al spaţiilor de învățământ (Vais, 2008).

Renașterea se remarcă prin apariția unor mari cărturari. Cehul A. Comenius (1592-1670), în Didactica magna, descrie importanța unui spațiu foarte bine gândit ca determinant în procesul educațional: „să pregătim mai întâi școala după cum pasărea își pregătește mai întâi cuibul” (Vais, 2008, p. 29).

Începând cu 1545, putem vorbi şi de prima grădină botanică din Europa, creată la Padova, care avea în primul rând rol educativ, fiind situată în cadrul Universităţii de Medicină. Ea reprezintă naşterea ştiinţei botanice, a progreselor științifice, dar joacă în acelaşi timp un rol esenţial în înțelegerea relației dintre om, natură și cultură (UNESCO, 1997).

Creșterea numărului de elevi din cadrul școlilor înregistrată în perioada secolelor XVIII-XIX accentuează relația îndrumător - grup de elevi. Perioada se face remarcată prin apariția planurilor variate, cu importanţă majoră până în zilele noastre, vorbim aici de plan de tip: academic clasic, compact academic şi popular (Vais, 2008, p. 29). Planurile unităților de învățământ de tip academic clasic se remarcau prin curți interioare, dar care ca şi în evul mediu, nu aveau funcție educativă. Tipul compact academic, utilizat cu precădere în a doua jumătate a secolului al XIX-lea, se bazează pe simetrie, compactitate, dispărând așadar curțile interioare. 
Martor stă planul Gimnaziului de la Frankfurt, care nu prezintă nicio relație cu spațiul exterior, concentrându-se pe partea teoretică a învățământului. lar cel de-al treilea plan, şi anume cel popular, prezintă inovații valabile până astăzi din punct de vedere funcțional, însă rămâne la fel de nepăsător cu privire la cadrul natural.

Anii '30 au generat ceea ce se definește ca „şcoală igienică”, cunoscută ca şi şcoală pre contemporană, cu elemente specifice, precum: lipsa rigidității, planuri semi-pavilionare sau tentaculare, clase de-a lungul coridoarelor, program arhitectural bogat. Un exemplu, nerealizat, este cel al Şcolii primare Bonnames din Frankfurt pe Main, proiectat după categoria planurilor tentaculare. Inovator este corpul sălilor de curs care dezvoltă o relație directă cu spațiul verde prin intermediul claselor în aer liber. Celelalte corpuri - sala de gimnastică şi lobby - delimitează împreună cu un aliniament de copaci, curtea de recreație, verde şi de dimensiuni mari, capabilă să acomodeze activități din cele mai diverse. Remarcabilă este lipsa împrejmuirii şi a unei bariere fizice clar conturate, aceasta făcându-se doar prin intermediul unei perdele verzi, dovedind caracterul liber al şcolii.

Corona School-Bell din Los Angeles, 1935, este un alt exemplu ce vine în sprijinul conceptului de scoală deschisă (Fig. 4). Cu toate că proiectul este o extindere a unei şcoli mai vechi, prezintă elemente inovatoare - sălile de clasă sunt dispuse numai la nivelul terenului şi au fost astfel concepute încât să permită extinderea lor către un spațiu în aer liber. O asemenea rezolvare asigură desfășurarea lecțiilor în aer liber, oferind „un contact optim al copilului cu natura, atât de necesar pentru dezvoltarea sa armonioasă" (Vais, 2008, p. 32).

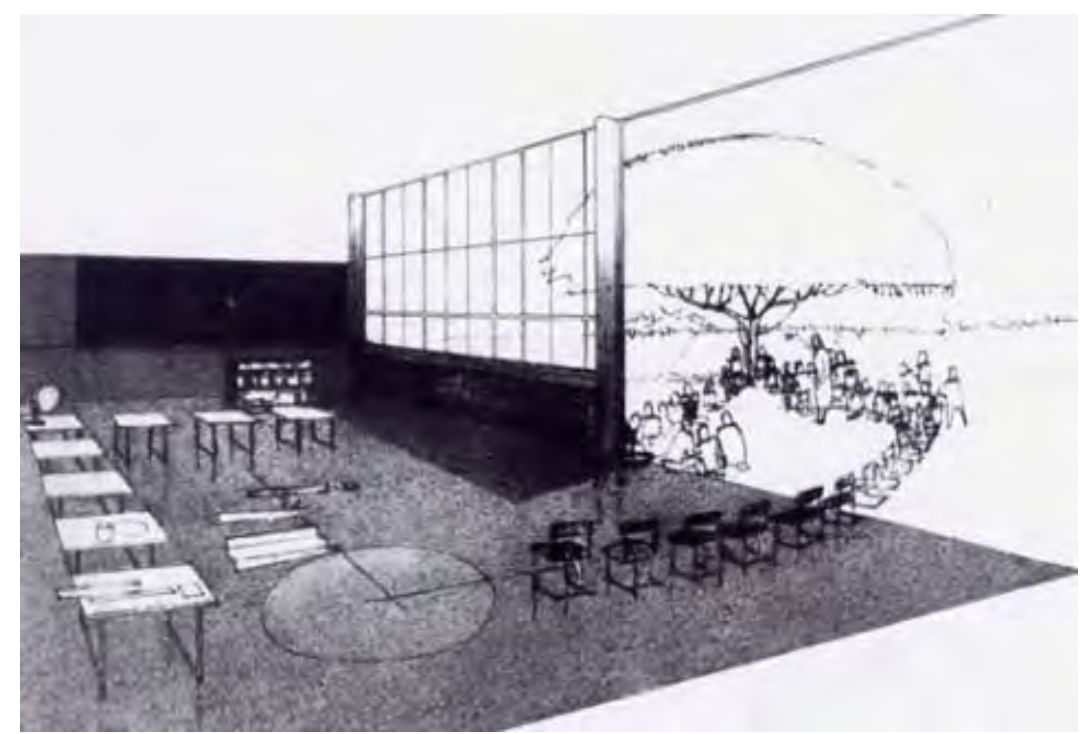

Fig. 4. Imagine din Corona SchoolBell, Los Angeles, 1935- Desfăşurarea lecțiilor în aer liber Sursa: http://www.etsavega.net/dibex/imatges/Neutra_3.jpg accesat 19.05.2018, imagine procesată de autor

În zilele noastre se fac remarcate două tendințe de proiectare a unităților de învățământ. Supraaglomerarea urbană, împreună cu necesitatea unei educații decente, fac ca școlile să nu dispună de spații exterioare destinate relaxării. Astfel de situații de compromis duc uneori la apariția spațiilor verzi situate pe acoperiș, însă acestea nu satisfac necesitatea copiilor şi a tinerilor de a înțelege mediul natural. Japonia este o sursă incontestabilă de astfel de exemple, precum grădinița Kiddy Shonan, din Kanagawa, a celor de la Suppose Design Office, care nu dispune de nicio relaţie cu exteriorul, toate activităţile petrecându-se în interior (Fig. 5). 
Amenajările exterioare la scară mult prea mare sau foarte mică fac subiectul celei de-a doua tendinţe. De exemplu, grădiniţa Hakemiya, din Kumamoto, realizată de Rhythmdesign şi CASEREAL, dispune de un spaţiu exterior tip curte interioară, de dimensiuni mult prea mici, cu dotări sărăcăcioase, remarcabilă fiind prezenţa unui arbore singuratic (Fig. 6).

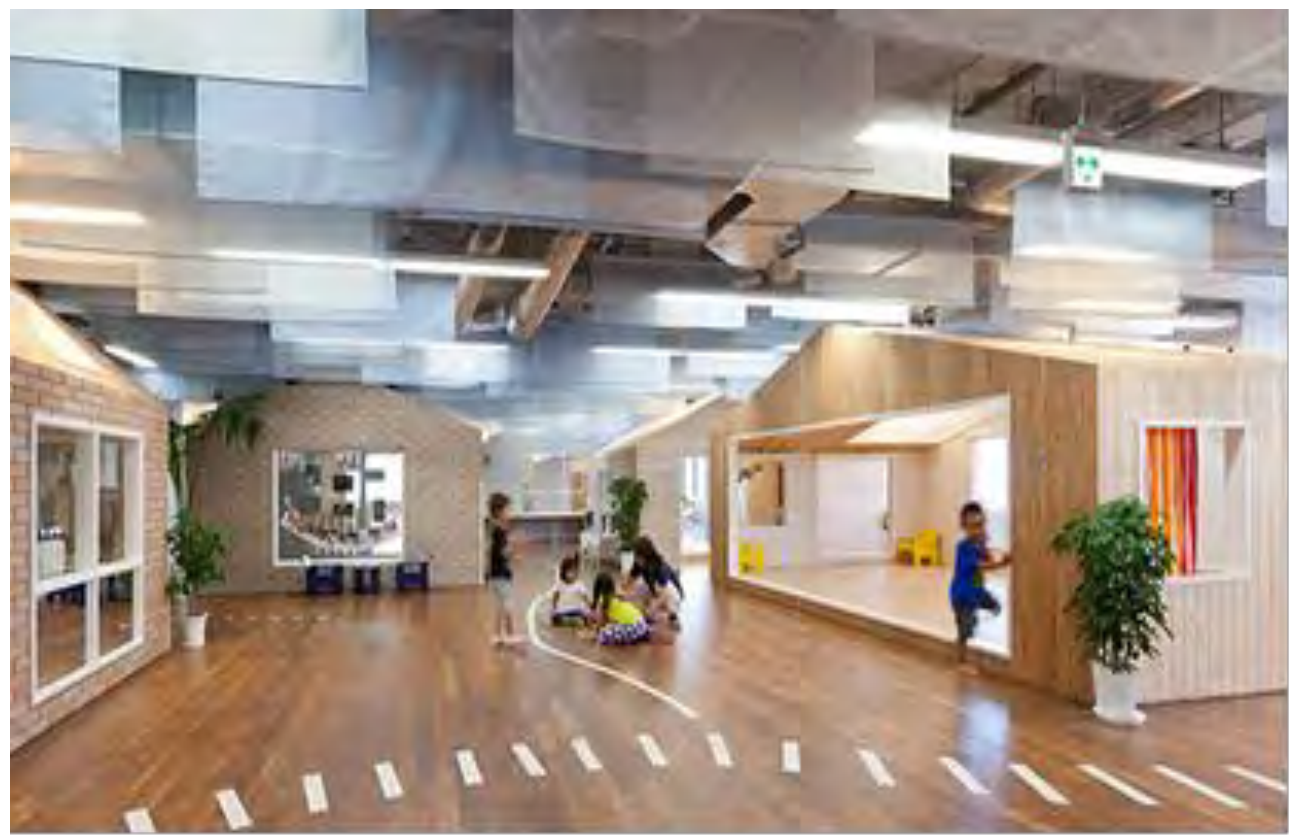

Fig. 5. Grădinița Kiddy Shonan, din Kanagawa. În proiectarea unității de învățământ cei de la Suppose Design Office nu au prevăzut niciun spaţiu exterior

Sursa: http://www.designboom.com/architecture/suppose-design-office-kiddy-shonan-cx-nursery-school/, accesat 19.05.2018, imagine procesată de autor

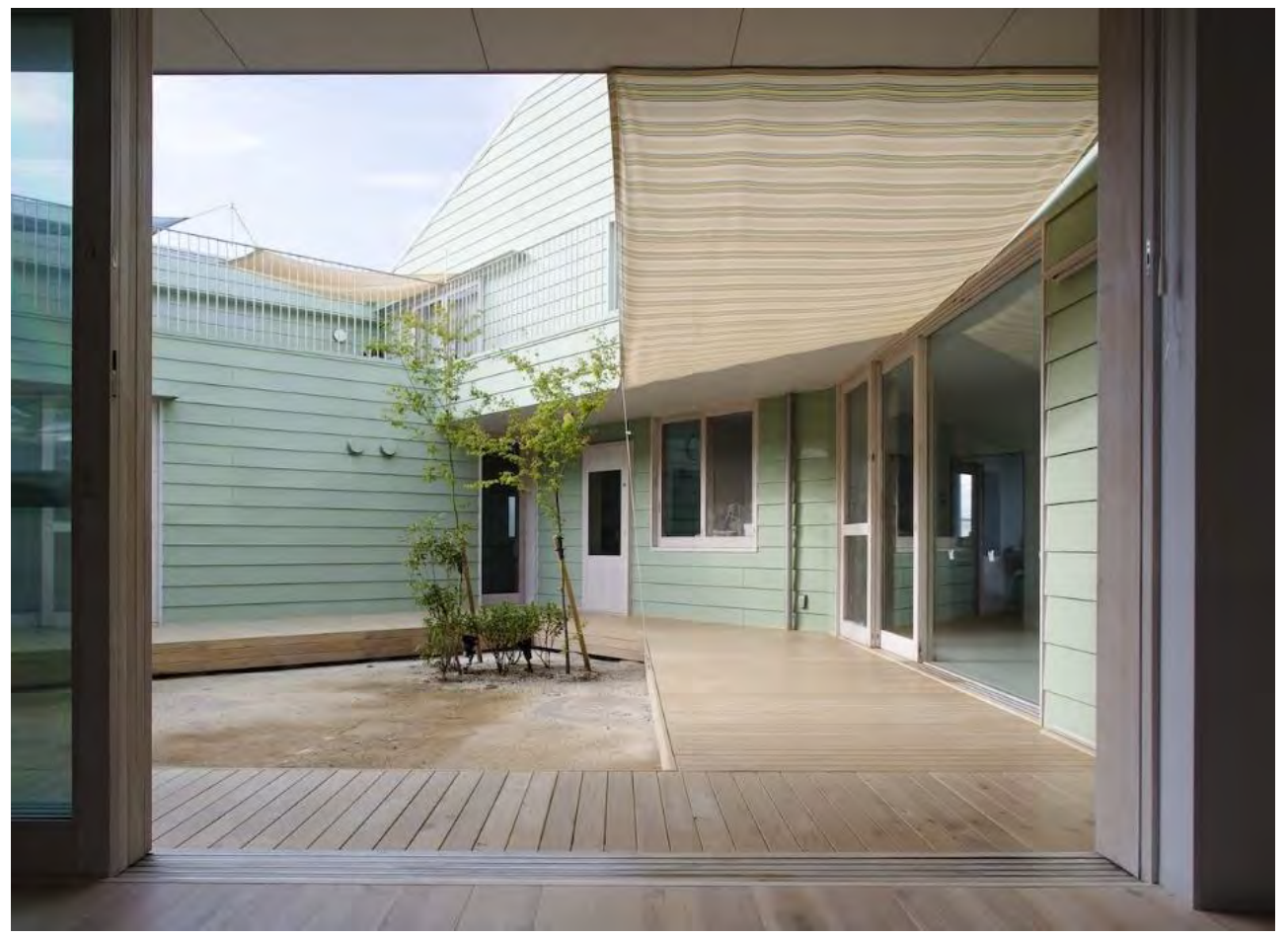

Fig. 6. Grădiniţa Hakemiya, din Kumamoto

- spaţiu exterior de dimensiuni mici, se poate observa lipsa dotărilor. Sursa: http://www.archdaily.com/592547/hakemiya-nursery-school-rhythmdesign-case-real/_, accesat 19.05.2018, imagine procesată de autor 


\section{Beneficiile învățământul în aer liber}

„Nu spunem la revedere sălilor de curs; le deschidem spre exterior"

Simon Beames, Lector la Universitatea din Edinburgh

Procesul de educație desfășurat în aer liber presupune angajarea copiilor și tinerilor în diferite activități. Profesorii trebuie să acționeze ca facilitatori, folosind abordări multi-senzoriale și experimentale, astfel încât cei mici să fie încurajați să se implice în experiențe emoționale, fizice, spirituale și cognitive, ca parte a procesului de învățare.

Locul în care oamenii se angajează în procesul de acumulare a informației îi ajută să facă conexiuni între experiențele lor și lumea din jurul lor într-un context semnificativ. Amenajările tematice, cu precădere cele destinate copiilor, oferă o diversitate de resurse și spații greu de reprodus într-un mediu interior. Fiecare tip de experiență cu caracter educativ în aer liber ar trebui să completeze o alta și să formeze o gamă progresivă și coerentă de experiențe pentru copii și tineri.

Există o bază substanțială de dovezi naționale și internaționale cu privire la beneficiile învățământului în mediul natural (Scotland, 2007, p. 7). Impactul acestora asupra copiilor şi tinerilor este în primul rând legat de sănătate și bunăstare, de dezvoltarea personală, de personalitate şi educaţie.

Există unele beneficii generale ale învățământului în cadrul natural, şi anume:

- conexiunile cu lumea reală din afara sălii de clasă sunt realizate experimental, contribuind la dezvoltarea abilităților, cunoștințelor și înțelegerii într-un context semnificativ;

- mediul exterior acționează ca un stimulent pentru creativitate și sporeşte procesul de învățare. Acesta aduce oportunități legate de provocare, anchetă, gândirea critică și recreație;

- elevii constată că nu tot ceea ce îi înconjoară se potrivește modelelor sau manualelor. Acest lucru nu înseamnă că ceea ce au descoperit este „greșit”. În schimb, se dezvoltă gradul de conștientizare a complexității lumii reale și poate contribui la dezvoltarea abilității de gândire critică;

- copiii și tinerii sunt capabili să înțeleagă relevanța unui subiect predat în școală raportat la viața de zi cu zi şi mediul înconjurător;

- $\quad$ studenții se pot comporta uneori diferit în aer liber. Elevii liniștiţi pot vorbi mai mult, alții devin mai calmi și mai concentrați, fiind influenţaţi de exterior şi în special de cadrul natural, vegetal;

- experiența multi-senzorială în aer liber ajută la memorarea eficientă a cunoștințelor;

- învățarea într-un mediu mai puțin structurat poate oferi o experiență de educație diferită de cel al clasei;

- experiența de învățare devine mai relaxantă pentru mulți elevi.

\section{Considerații de proiectare a spațiilor de recreație anexate unităților de învățământ}

Multe dintre tipurile de activităţi recreative pot avea loc spontan în spaţii care nu necesită amenajări speciale (în cadrul unei locuinţe sau în spaţii publice - strada, parcul, piaţa etc), însă 
unele componente ale loisirului, precum cultura sau sportul, sunt deseori condiţionate de spaţii şi amenajări tematice specifice. De exemplu, sălile de spectacol, de lectură sau mediatecile prezintă necesitatea unui spaţiu exterior foarte bine gândit, acesta transformânduse, în anumite situaţii, în cadre pentru activităţi culturale, pe când anumite jocuri sau sporturi pot fi practicate numai pe terenuri de dimensiuni standard, iar asistarea la astfel de evenimente implică prezenţa unor dotări tipice - amenajări de tip gradenă. Aceste spaţii specializate recreerii sunt „generate şi generatoare de comportament social” (Chira, 1998, p. 22), deci este necesar în prealabil un studiu asupra amplasamentului dotărilor de loisir în funç̧ie de contextul social şi geografic pentru o analiză a necesităţii funcţiunii şi a impactului acesteia asupra zonei de intervenţie. Fiabilitatea şi flexibilitatea spaţiilor reprezintă de asemenea un aspect important pentru a asigura o exploatare continuă şi adaptabilitatea necesară unei bune funcţionări a obiectului pe termen lung.

Următoarele patru principii, și anume cantitatea, calitatea, bunele practici și viziunea, sunt aspectele relevante în planificarea și furnizarea facilităților exterioare de recreere:

a) Cantitatea: amenajările exterioare şi spaţiile de recreație şi sport ar trebui furnizate pentru a satisface cererea celor mai populare activități, „de bază”, în cadrul fiecărui district de planificare;

b) Calitatea: facilitățile de recreere şi spațiile exteriore, deschise, furnizate ar trebui să fie de înaltă calitate, vorbim aici de instalații, aspect exterior și design. Sunt necesare pentru a satisface nevoile și aspirațiile utilizatorilor;

c) Bune Practici: prin intermediul unui acces facil, trebuie să se încurajeze utilizarea optimă și să permită îmbunătățiri complementare. Ar trebui, de asemenea, să fie furnizate medii de recreere integrate și cadru vegetal deschis care să definească un caracter pietonal zonei. În atingerea acestui obiectiv, ar putea fi necesar, în unele situații, să se depășească limitele minime stabilite pentru standardele de furnizare. Cadrul, precum și componentele individuale, ar trebui să fie revizuite periodic pentru a ține seama de orice modificări posibile în funcție de nevoile utilizatorilor.

d) Viziune: în implementarea unei zone de recreere atractive trebuie să se ţină cont de caracteristicile de amplasament, de structura populației și de cadrul social-economic, precum şi de timpul alocat odihnei. Când proiectarea se adresează unei anumite grupe de vârstă, cu precădere copiilor şi tinerilor, flexibilitatea utilizării este esențială. Aceste spații trebuie să integreze caracteristici din cele mai diverse pentru a atrage publicul ţintă, să permită practicarea sporturilor „extreme” prin prezența unor instalații speciale. Trebuie, de asemenea, să fim atenţi şi să ţinem cont de furnizarea și accesibilitatea facilităților pentru grupurile speciale, cum ar fi persoanele cu handicap.

\section{Mediul exterior prin ochii unui copil}

Jean Piaget și Bärbel Inhelder (1956), cunoscuți pentru studiile epistemologice cu copii şi teoria cognitivă, susțin în lucrarea „Percepția copilului asupra spațiului” că dezvoltarea copiilor este rezultatul interacțiunii dintre mediul social şi cel natural. De asemenea, ei afirmă că de la naştere până la vârsta de 18 ani, copilul dezvoltă de la o gândire egocentrică, bazată pe reflexe şi pe un model comportamental general, o gândire logică, simbolică și abstractă.

De la Proust putem învăța cum prezența naturii în educația unui copil este esențială şi, mai cu seamă, cum dragostea pentru natură se naște în copilărie şi se menține pe parcursul vieții. 
Abilitățile unui copil de a se atașa emoțional de un loc țin de capacitatea unui spațiu de a deveni special, de a oferi confort și mai ales de a provoca bucurie şi amuzament. Putem afirma că un spațiu poate să aducă siguranță într-o lume atât de instabilă, mai ales din punct de vedere cultural şi social, că micile ascunzători sunt stabile şi nu pot dezamăgi, fiind demne de toată dragostea unui copil, chiar şi după ce acesta devine adult (Cele, 2006, p. 14).

Modul în care copiii transformă locurile neutre în adevărate temple de joacă, atât de speciale și uneori „secrete”, stă în mișcări simple, precum mutarea unor bețe sau crearea unei movile din pietre. Aceste manipulări ale vegetației sau ale terenului sunt deseori atât de mici încât doar un copil le poate percepe adevărata valoare. Peisajul şi mediul natural influențează comportamentul copiilor, joaca şi mai ales educația, fiind actorii principali din viaţă unui copil sănătos. Remarcabil este şi simțul de proprietate al copiilor, necesitatea tinerilor de a transforma locul este strict legată de acest sentiment şi mai cu seamă de senzația de „acasă” pe care ulterior acesta o poate transmite.

Diferite studii realizate în Suedia și Anglia (Cele, 2006, p. 12) arată cum experiențele unui copil asupra spațiului sunt multidimensionale, formate atât din procesul concret -simțuri - cât și din cel abstract - emoții. Metodele interactive de învățământ plasate în mediul de joacă, spațiu exterior, permit copiilor să beneficieze de o experiența directă, iar actul educativ se petrece în subconștient prin mișcare, joacă sau pur şi simplu recreație.

Vegetalul, verdele din mediul înconjurător, are rolul de a provoca o mare varietate de stimuli, şi mai cu seamă are capacitatea de a ne face să uitam de timp şi spațiu, să ne concentrăm mai mult pe activitatea curentă decât pe cea trecută sau viitoare. Necesitatea lui devine mult mai proeminentă în cadrul mediilor urbane. Nabham şi Trimble vorbesc în 1994 despre situația copiilor din cadrul urban, cu precădere despre noile abilitați ce ar trebui dezvoltate, precum cea de a „călători dincolo de trotuar, pentru a avea acces la vegetație și pământ, care le permite să se cațăre şi chiar să cadă" (Nabham; Trimble, 1994, p. 24). Putem vorbi, așadar, despre cum tinerii se angajează social, intelectual şi mai ales emoțional cu natura când se joacă în cadrul ei, învață de la ea, deci încep să îşi contureze un comportament ocrotitor. Uneori uitam de bucuria pe care o simțeam când ne căţaram într-un copac, de multe ori după fructe ce nici măcar nu erau coapte, şi devenim brusc precauți. Amenajările exterioare destinate copiilor şi tinerilor sunt bazate pe siguranță, deci nu sunt provocatoare şi nu au capacitatea de a dezvolta coordonare, flexibilitate, concentrare.

Putem afirma că percepția unui copil asupra mediului înconjurător este total diferită faţă de cea a unui adult. Copiii trăiesc într-o lume diferită decât cea a adulților, o lume mult mai vie. Însă, realitatea celor mici este puternic ancorată în lumea celor mari, putem discuta totodată de o îndepărtare socială când vine vorba despre proiectarea spațiilor destinate elevilor. Din acest motiv, cercetările realizate, cu şi despre copii, capătă din ce în ce mai multă atenție din domenii vaste precum: arhitectură, peisagistică, sociologie, pedagogie etc.

Totuşi, provocările metodelor noi de proiectare nu apar din înțelegerea faptului că la un anumit grad copiii simt și percep diferit mediul decât adulții; problema principală constă în înțelegerea acestor diferențe și posibilitatea de eliminare a lor prin punți de înțelegere reciprocă. lar acest lucru este decisiv când analizăm sau proiectăm spații exterioare în cadrul unităților de învățământ. Aceste zone sunt menite, totuşi, să deservească simultan atât copiii sau adolescenții, cât şi cadrele didactice; să nu uitam că pauzele sunt pentru toţi cei implicați în procesul educațional. 


\section{De vorbă cu un arhitect, sociolog şi educator - experiență personală}

\section{Despre Frode Svane}

Pe Frode Svane I-am cunoscut pe una din cele mai mari platforme de socializare, Facebook, în timpul studiului de cercetare realizat în timpul studiilor doctorale. Provine din Norvegia şi spune despre el că este arhitect, arhitect peisagist, educator şi sociolog. Tine, totuşi, să menţioneze că face lucrul acesta de peste 40 de ani şi că „această atipică combinaţie de cunoștințe şi experienţe" I-au forțat să dezvolte un interes adânc în implicarea utilizatorilor în procesul de creație.

Statutul de educator îi oferă o relaţie specială, apropiată, cu tinerii, iar acest lucru se vede în majoritatea lucrărilor sale destinate celor mici şi recunoaște că utilizează școlile pentru cercetarea şi implementarea unor proiecte: „Folosesc foarte des școlile, ca o baza a procesului de dezvoltare, în care copiii şi tinerii primesc cea mai bună oportunitate de a învața despre mediul înconjurător şi de a-I schimba".

\section{„Participarea şi implicarea crează angajament şi responsabilitate!”}

Întrebat despre ce părere are cu privire la rolul participării active a copiilor „urbani” în cadrul natural, arhitectul răspunde clar și concis: „Nu cred că acest aspect trebuie explicat, totuşi, e foarte simplu: participarea, implicarea şi aportul fiecăruia este chiar mai important pentru copiii şi tineri care se dezvoltă în marile conurbații, fie că aceştia cresc în centru sau într-o suburbie". Aşadar, societatea trebuie să fie capabilă să accepte participarea şi intervențiile tinerilor ca cetățeni cu gânduri şi viziuni. Aportul lor poate aduce schimbări reale în cartier sau chiar în societatea locală, care devine un cadru important atunci când aceștia vor atinge o alta categorie de vârstă.

În interviul acordat, Frode Svane, vorbeşte şi despre arhitectură şi natură, precum şi despre rolul ei în educaţie: „Modul cel mai eficient de a face un copil sau un tânăr conştient de arhitectura înconjurătoare şi de măreţia mediului înconjurător, este prin acordarea şansei în perioada de creştere de a participa la procesul de creaţie a spaţiilor, fie ele clădiri sau spaţii verzi. Această şansă de implicare în schimbarea şi crearea de locuri noi, sau pur şi simplu de îmbunătățire a celor existente, trebuie oferită în spaţiul lor: şcoala."

De asemenea, un alt aspect important în implicarea copiilor şi tinerilor în astfel de proiecte, aşa cum a fost discutat şi în aspectele teoretice, stă în ideea de „apartenență”. Este un sentiment de care copiii sunt extrem de ataşaţi, pentru că, inconştient, acesta generează responsabilitate faţă de un loc. Frode Svane a fost arhitect şef în oraşul Lørenskog timp de 4 ani şi, spune el, a făcut din această experienţă o misiune pentru un învăţământ mai decent. A implementat un proiect intitulat "Crescând în Lørenskog" - primul dintr-o lungă serie de proiecte ce vizează implicarea activă a copiilor şi tinerilor în procesul de planificare a utilizării teritoriilor municipale. Îşi aminteşte cum, în timpul unui proiect din cadrul unei şcoli, copiii au dezvoltat „un simţ de proprietate, diferit faţă de cel al unui adult - este curtea noastră de care NOI avem GRIJĂ!"

Știm cu toții că din momentul în care reuşim să atragem atenția unui copil asupra unui lucru, acesta dezvoltă o pasiune deosebită, făcând o misiune din el, până se plictisește. Frode este de acord cu acest lucru şi spune că lucrul cu tinerii trebuie să fie constituit din „sesiuni speciale de maxim jumătate de oră, suficiente pentru a stârni interesul şi pentru a crea dorința de viitoare participări". 
Cu timpul, arhitectul a observat un tipar şi consideră că o participare organizată poate duce la:

1. responsabilitate - participanții activi au grijă mult mai mare de mediul înconjurător;

2. afiliere puternică cu locul;

3. angajament;

4. identitate - locul reflectă nevoile comunității;

5. coeziune - întăresc contactul social indiferent de vârstă, sex sau cultură;

6. abilități legate de munca în echipă;

7. nu mai apare tendința de vandalizare; 8.tendinţa de violenţă şi conflict se atenuează remarcabil.

\section{Importanţa naturii în formarea tinerilor şi mai apoi importanţa oamenilor în formarea naturii}

Am observat, din studiile anterioare, că educaţia este strâns legată de o minte sănătoasă aflată într-un corp sănătos. Natura are rolul de a participa direct în formarea personalităților şi a încrederii în sine, iar mai apoi această educaţie se răsfrânge asupra mediului înconjurător.

Norvegienii au o legătură specială cu natura, iar aceasta se vede în respectul pe care aceștia Iau demonstrat de-a lungul anilor faţă de păduri. Aşa cum însuşi Frode Svane afirma într-unul din interviurile sale despre proiectul Loc de joacă în pădurile Norvegiene: "Norvegienii dezvoltă o relaţie stransă cu pădurea locală sau cu natura încă de la vârste fragede. În această ţară oamenii obişnuiau să trăiască în natură, iar noi am realizat că ne naştem cu sentimentul de protecţie şi ocrotire a spaţiului verde şi credem că un mediu natural cu caracter educativ este benefic pentru toată lumea"( Nakamura, 2003, p. 15).

Modul cel mai simplu de a stabili acest sentiment este prin intermediul amenajărilor exterioare, fie ele educative sau nu, însă cu siguranță anexate școlilor. Spațiul exterior imediat apropiat unităților de învățământ este locul în care copiii din întreaga lume trebuie să-şi petreacă majoritatea timpului, cu sau fără voia lor. Transformarea acestor spații verzi este, așadar, necesară şi se bazează pe adevăratele nevoi ale copiilor. Dialogul dintre interior şi exterior trebuie să fie sincer şi trebuie construit pe cunoștințe aprofundate cu privire la modul în care copiii învață cu adevărat. Exteriorul trebuie sa producă entuziasm utilizatorilor: „este lipiciul care grăbește acumularea de informații de către corp!" (Frode Svane, interviu acordat în 05.05.2018).

\section{Învățând prin joacă - studiu de caz}

În cadrul ultimelor două milenii, China a fost o civilizație cu o structură socială aristocratică. Sistemul de învățământ de stat este considerat, la fel ca în restul lumii, a fi unul riguros şi tradiţional, cu o educaţie puternic influențată de filosofia transmiterii în mod unilateral a cunoștințelor din generație în generație. În epoca prosperității economice și a globalizării, cursul procesului de educației a suferit modificări, fiind drastic schimbat. Elevilor li se acordă dreptul de a se aventura în vastul univers al cunoașterii, de a-şi deschide noi orizonturi prin dezvoltarea unei personalități şi înțelepciuni proprii, precum și capacitatea de a-şi dezvolta o gândire critică. 
Cei de la Gravity Green au fost inspirați de această mișcare în timpul proiectării campusului destinat liceului Yi Zhong De Sheng din sudul Chinei, în care elevii sunt încurajați să interacționeze cu peisajul prin intermediul amenajărilor tematice educative și, prin urmare, să caute cunoștințe în mod proactiv. Proiectul finalizat în 2010 se întinde pe o suprafață de 12,500 de $\mathrm{m}^{2}$ şi deservește peste 2800 de elevi, cu programe şcolare diversificate, la care cadrul exterior nu rămâne imparțial (Fig. 7).

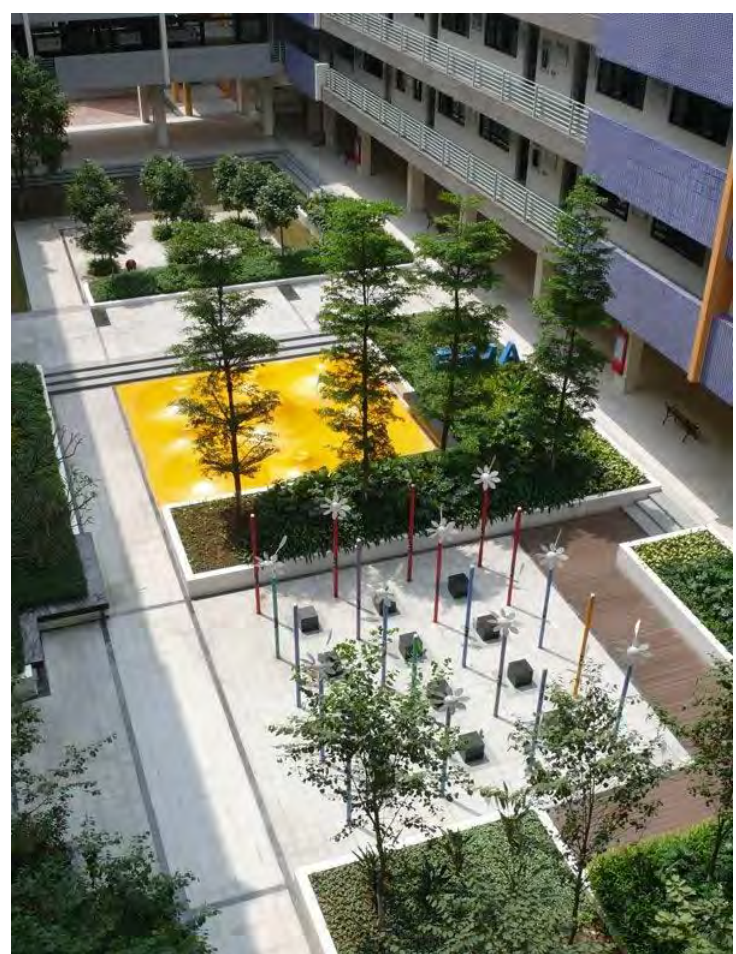

Fig. 7. Imagine de ansambul din cadrul proiectului Liceului Yi Zhong De Sheng din sudul Chinei, Gravity Green

Sursa: http://www.gravitygreen.com /works /institutional\#yi -zhong- de- sheng- secondary-school, accesat 17.05.2018, imagine procesată de autor.

Campusul este dezvoltat după planul de tip „finger”, fiind format dintr-o serie de patru blocuri multietajate destinate procesului educativ. Clădirile formează un număr de spații exterioare între ele, protejate pe toate laturile, fapt ce a oferit arhitecților oportunitatea de a transforma cadrul natural într-un mediu educativ vibrant și prin intermediul unor elemente specifice au revitalizat uniunea arhitecturală.

Curțile, de tip atrium, au căpătat valențe din cadrul a trei discipline academice: fizică, artă şi geografie, deci un subiect precis ce reflectă activitatea didactică din cadrul corpurilor ce îl înconjoară. Din aceste domenii largi, s-au ales subiecte concrete precum: Legea Universală a Gravitaţiei, simbolic denumită Sir Isaac Newton, Legea de conservare a energiei, Movilele Energiei Cinetice şi Ferma Eolienelor (Fig. 8), cel de-al treilea fiind Demografia (Fig. 9). Toate dotările dispun de setări activ-educative, transpuse ingenios într-un cadru jucăuș. Aceste spaţii nu sunt doar amenajări exterioare destinate recreaţiei, ci sălile de clasă în aer liber, dotate cu elemente sculpturale, culori diverse și instalații de stimulare vizuală, capabile să stimuleze curiozitatea elevilor, să le menţină interesul, și să declanșeze dorința lor de a atinge, de a interacționa, de a examina, de a experimenta, și, în cele din urmă, de a își aprofunda cunoștințele fundamentale. 


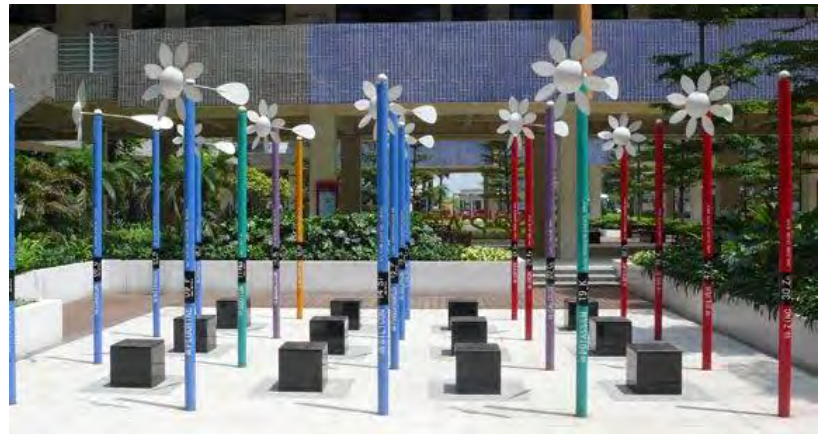

Fig. 8. Grădina Ferma Eolienelor

Sursa: http://www.gravitygreen.com /works /institutional\#yi- zhongde- sheng- secondary-school,

accesat 17.05.2018, imagine procesată de autor

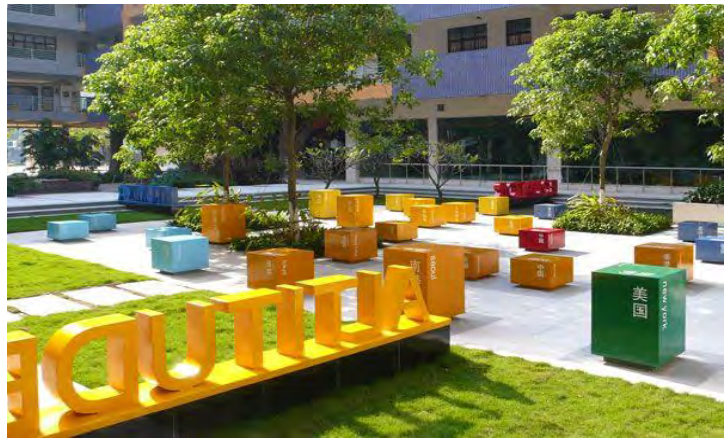

Fig. 9. Grădina de geografie

Sursa: http://www.gravitygreen.com /works /institutional\#yizhong- de- sheng- secondary-school,

accesat 17.05.2018, imagine procesată de autor

Tendinţa de a crea spaţii destinate socializării directe nu este nici ea ignorată. Intenţia arhitecţilor poate fi trecută prin filtrul teoretic, cu precădere, de modul în care copiii percep spațiul. Cei de la Gravity Green au reuşit prin intermediul amenajărilor tematice cu rol educativ să creeze spaţii multi-senzoriale, care satisfac nevoia copiilor de a cunoaște, socializa şi totodată de a asimila informații în mod inconştient. Diferite studii realizate în Suedia și Anglia (Cele, 2006, p. 12) arată cum metodele interactive de învățământ plasate în mediul de joacă, spațiul exterior, permit copiilor să beneficieze de o experiență directă, iar actul educativ se petrece în subconștient prin mișcare, joacă sau pur şi simplu recreație.

Importanța jocului în învățare și dezvoltare de la copilărie la maturitate este vitală în fiecare etapă a vieții și diferită prin forme, stiluri și semnificații. Copiii răspund într-un mod pozitiv atunci când informațiile sunt livrate într-un spațiu vesel, într-un mediu non-academic sau de activitate profesională. Cu alte cuvinte, învățarea ar trebui să fie un ciclu interactiv, virtuos, în care copiii participă activ prin observare, integrare, explorare, intuiție, aplicare şi prin procese ale comportamentului uman stimulate de mediul natural.

Un spațiu de învățare prin joacă deschide posibilități noi pentru indivizi, prin acordarea posibilități de a deveni intrinsec motivați să se definească pe ei înșişi, precum şi să învețe îndemnați de propria lor curiozitate și dorință. Acest proiect este un exemplu de organizare a spațiului exterior, ce înglobează elemente din cele mai diverse domenii (arhitectură, fizică, geografie) în peisagistică, precum și impactul pozitiv al unui design inteligent integrat.

\section{Concluzii}

În prima parte a studiului s-a demonstrat că, pe parcursul timpului, spațiile destinate activităților exterioare din cadrul unităților de învățământ au jucat un rol important în organizarea funcțională a instituțiilor, căpătând ulterior valențe estetice. Am observat, de asemenea, că raportul dintre spațiul interior şi cel exterior este dictat de tendințele epocii. Fiecare civilizație marchează evoluția sistemului de învățământ, dar şi spaţiul destinat procesului. Dacă de la greci putem culege primele beneficiile ale unui învățământ în aer liber, din perioada Evului Mediu putem distinge caracterul privilegiat al școlilor în cadrul societății. Inovațiile asupra spațiilor verzi apar abia în 1930, când din ce în ce mai multe proiecte, realizate sau nu, dau dovadă de flexibilitate, spirit liber și creativitate. Așadar, putem vorbi de amenajări peisagere, care profită de cadrul natural şi vegetal pentru a transmite date în subconștientul copiilor, sporind interesul pentru natură, capacitatea de concentrare, deci învățare. 
Cea de-a doua parte a lucrării pornește de la tendința copiilor moderni de a sta cât mai mult în casă pentru că „,acolo sunt toate electronicele şi jocurile” (Louv, 2005, 9). Provocarea este cum reușim ca prin intermediul amenajărilor să stârnim interesul adolescenților să petreacă mai mult timp în universul exterior, departe de monitoare. Domenii precum: geografia, arhitectura, peisagistica sau sociologia sunt doar câteva ce își pun această problemă şi încearcă să dezvolte studii dintre cele mai variate pentru a elabora soluţii concrete şi eficiente. Consider că un prim pas sunt activitățile din cadrul școlilor, precum şi amenajările tematice exterioare educative. Copiii sunt nevoiți să petreacă o bună parte din viaţa lor în cadrul acestor unități de învățământ, iar o educație de calitate se bazează, în primul rând, pe sănătatea mentală şi fizică.

Mediul exterior prin ochii unui copil arată cu totul diferit, deși realitatea lor este puternic ancorată în activitățile adulților. Așa cum afirma Proust, dragostea pentru natură se naște în copilărie şi este atât de pură încât se menține şi la maturitate. Observăm că tinerii se angajează social, intelectual şi mai ales emoțional cu natura când se joacă în cadrul ei, învață de la ea, deci încep să îşi contureze un comportament de ocrotire.

Un alt mod de atragere a copiilor şi tinerilor în cadrul natural este strâns legat de sentimentul de proprietate şi cel de „acasă”. Felul în care aceștia reușesc să se atașeze de un loc constă în lucruri simple, iar intervențiile acestora în cadrul exterior, deși mici, fac diferența. Însă şi aici apare o problemă legată de ego-urile profesioniștilor, care orbiți de reguli şi normative au tendința de etichetare a spațiului prin filtrul teoretic, fără să-şi pună probleme legate de funcționalitatea spațiului exterior şi de sensibilitatea unui astfel de cadru. Capacitatea copiilor de a influenţa şi de a participa la astfel de proiecte depinde de voinţa adulților de a asculta, dar şi de modul în care dorințele şi sugestiile lor sunt interpretate.

Știm că un copil se atașează sincer, că face dintr-un lucru important pentru el o adevărată misiune şi nu dă înapoi decât atunci când se plictisește. Dacă reușim să înțelegem că natura joacă un rol important în dezvoltarea copiilor şi tinerilor, că modul lor de percepție a cadrului natural este diferit faţă de cel al adulților, împreună cu necesitatea implicării directe a copiilor, putem defini câteva reguli de aur în proiectarea acestor spaţii.

Prin implicarea directă a copiilor şi prin posibilitatea ca fiecare să-şi lase amprenta în spațiul exterior aferent clădirii de învățământ, putem reuși să formăm o dedicare subconștientă a copiilor de a păstra şi proteja natura. După cum am precizat, copiii au nevoia să simtă că locul le aparține, iar pentru a atinge acest scop sentimentul de proprietate trebuie subtil creat, pentru ca spaţiul să devină singur atractiv, fără a fi impus.

\section{Referinţe}

Cele, S., 2006. Communicating Place - Methods for Understanding Children's Experience of Place,, Stockholm: Departamentul de Geografie, Universitatea din Stockholm;

Chira, M., 1998. Direcţii de dezvoltare a centrelor destinate sporturilor de recreere, Bucureşti: s.n.;

Gravity, 2009. yi zhong de sheng secondary school.

Accesat 14.0.20158: http://www.gravitygreen.com/works/institutional\#yi-zhong-de-sheng-secondaryschool;

Iliescu, A.-F., 2003. Arhitectura Peisageră. Bucureşti: Ceres;

Nabham şi Trimble, 1994. The Geography of Childhood. Why children need wild places. Boston: Beacon Press; 
Nakamura, A., 2003. Landscape design in Scandinavia:

http://happa88.life.coocan.jp/landscape_design_in_scandinavia.pdf

Piaget, J. și Inhelder, B., 1956. The Child's Conception of Space. Londra: Routledge\&K.Paul;

UNESCO, 1997. Botanical Garden (Orto Botanico), Padua.

Accesat la 14.05.2018: http://whc.unesco.org/en/list/824.

Scotland, E., 2007. Taking Learning Outdoors: Partnerships for Excellence. Glasgow: Deputy Education and Young People Minister;

Vais, G., 2008. Programe de Arhitectură. Cluj-Napoca: U.T.Press;

Vişoiu, D., 2001. Istoria grădinilor şi parcurilor. Timişoara: Mirton 


\title{
LEARNING THROUGH PLAY \\ RECOVERING THE OUTDOOR SPACES WITHIN SCHOOL INSTITUTIONS
}

PhD. arch. Diana Popa

"Ion Mincu" University of Architecture and Urban Planning, Bucharest

gogoasa.diana.arh@gmail.com

\begin{abstract}
This paper closely analyses the outdoor spaces surrounding the school institutions from a historical perspective and referring also to the way they have been evolving according to determining factors, context, and the needs of each historical period. The theoretical study focuses on the thematic arrangements with an educational character and the way in which leisure spaces connected to education have a significant role in the development of teenagers, thus becoming mostly educational.

The tendency of modern children is to spend more time inside, because "there you can find all the electronics and games" (Louv, 2005, p. 9), has become more and more a debate issue. The question this study tries to answer to is: "How do we manage, by means of arrangements, to arise the interest of adolescents in order for them to spend more time far away from the monitors?"

Firstly, the paper seeks to explore, from the historical point of view, and considering the relation between the indoor and outdoor space, the need for green educational spaces attached to school institutions. One can notice the way in which they gradually evolved, from closed yard-type spaces which perfectly fitted the functional requirements and the seclusion spirit specific to the Middle Ages society, to thematic spaces defined by the integration of sports, and reaching at present to spaces capable to stimulate the creativity and the intellect of children by means of their pro-active involvement.

Secondly, the research analyses a special international project of landscape arrangements with an educational and thematic character. This detail-conducted investigation contributes to identifying and explaining the possibilities to view more comprehensively the indoor-outdoor relation. The project which has been chosen as a case study has demonstrated in real time the ability to sustain and consolidate the inner functions, by means of transfer and extension in the exterior space, and also the ability to stimulate the children's capacity to interact in the natural environment.
\end{abstract}

Keywords: recovery of outdoor spaces, educational units, indoor-outdoor relation, educational architecture 


\section{Short history of the indoor-outdoor relation within the school institutions}

Many studies are based on detailed research on human health. Most of them indicates the fact that human health is influenced not only by the equilibrium with the environment, but also by the relation between the physical or intellectual activities and the leisure activities. In choosing the leisure forms and the specific facilities it is interesting to investigate: the available free time, the dimension of the site, the users' preoccupations, and dispositions (Iliescu, 2003, p.101). Within the school institutions it is well-known the leisure and time factor, the school breaks, but a short history connected to the evolution of spaces helps us understand how this type of places are used, as well as the way in which the needs vary according to each historical period.

The first organized school institutions appear in the Euphrates Area (Nineveh, Babylon) and are destined especially to the formation of scribes ${ }^{1}$. These begin to have an academic structure once the libraries are being attached, starting with the $18^{\text {th }}$ century BC. Therefore, the evolution from one room, necessary for the teacher-pupil relation, to large spaces with multiple functions can be considered a major change, both from the point of view of landscape architecture and architecture.

The Ancient Egypt promotes for the first time the idea of collective instruction, but also the idea of being in communion with nature. The study hours were taking place especially within palace courts or instruction centres ${ }^{2}$. Although it is not the case of abundant vegetation in those areas, the gardens, little in number, became natural oasis in dessert-like landscapes, being generally populated with sycamores, dates, pomegranates etc. Another important aspect of the Egyptian gardens is given by the rectangular basin populated with coloured fish and decorated with lotuses, the landscape being well framed with lines of trees, demonstrating the specific refinement of the Egyptian art, and also the need of a contact with nature in everyday life.

In Ancient Greece, the children's education is very different in Sparta and Athens. On the one hand, the Spartan child belonged to the state starting with the age of 7, and his education consisted and was limited to hard physical training, whereas the intellectual instruction was minimal. The spaces destined for practicing sports appear as a dominant feature of the outdoor landscape of the school. On the other hand, there were the teeanagers in Athens. The educational system was divided in two levels: the school of the grammarian - in which the educational activity was carried on in the private houses or under the town's porticos, and the gymnasium and palaestra - "each town, no matters how small it was, had a theatre and a gymnasium" (Vais, 2008, p. 26).

During the Hellenistic period, the gymnasium became one of the main actors within the city, enjoying a central position, very often being attached to the agora. In the $5^{\text {th }}$ and $4^{\text {th }}$ centuries $\mathrm{BC}$, the first designed gardens have been created near the gymnasiums and academies. These were of relatively small dimensions, with less rigorous paths and numerous decorative elements: pergolas, porticos, fountains, statues, creating an aesthetic background completed with vegetation (Iliescu, 2003, p. 101). The gardens were spreading as inner-yard spaces having a special functional value in which educational activities were taking place, a thing which demonstrates the importance of exterior background in the life of Greeks and their capacity to

\footnotetext{
${ }^{1}$ Functioneers in administration and temples.

${ }^{2}$ Temples.
} 
integrate nature with more and more diverse functions. Around this space rooms were being constructed with a strict educational character: libraries, course rooms, bathrooms (ablutio) and others (Vais, 2008, p. 27). The most interesting case studies of gymnasiums and palaestras are the examples from Olimpia (Fig. 1), Priene and Milet (Fig. 2) in which one can notice the proximity and even the direct contact of the educational spaces with the water.

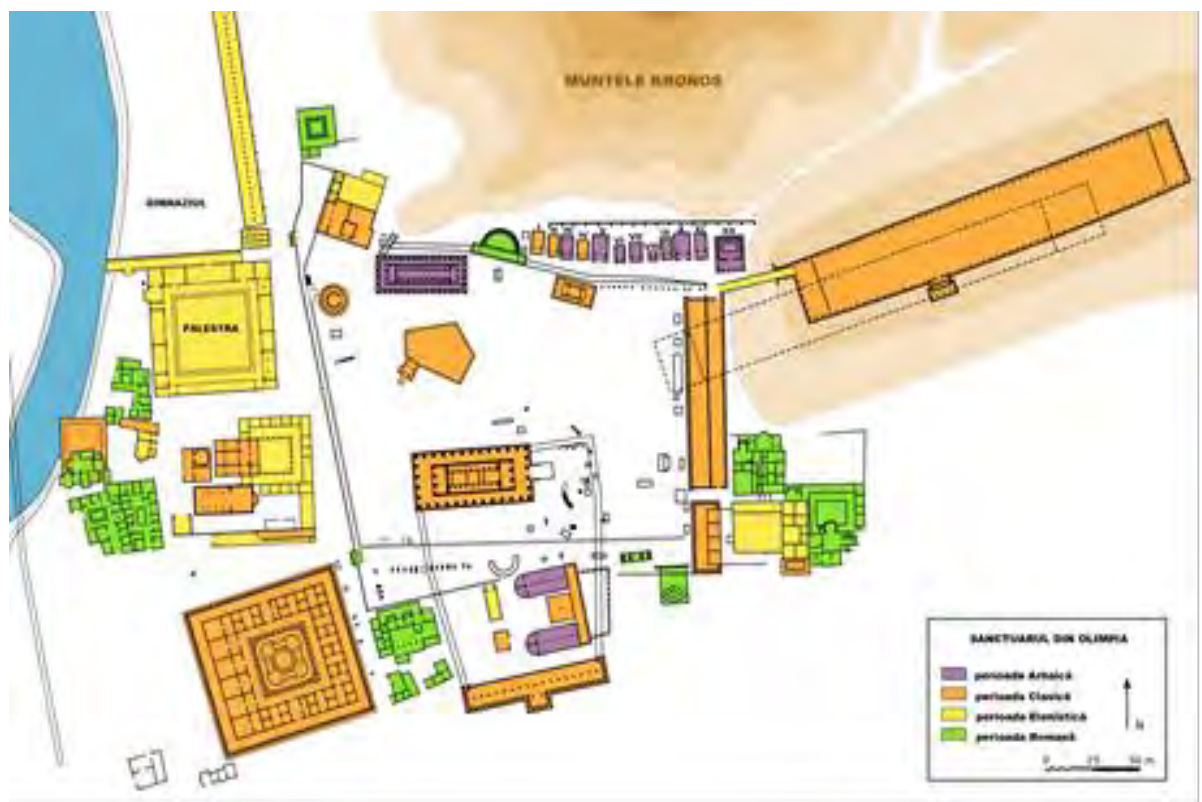

Fig. 1. The plan of the city of Olimpia highlighting the gymnasium and the palaestra Sursa: https://en.wikipedia.org/wiki/Olympia,_Greece, accesat 17.05.2018, image processed by the author

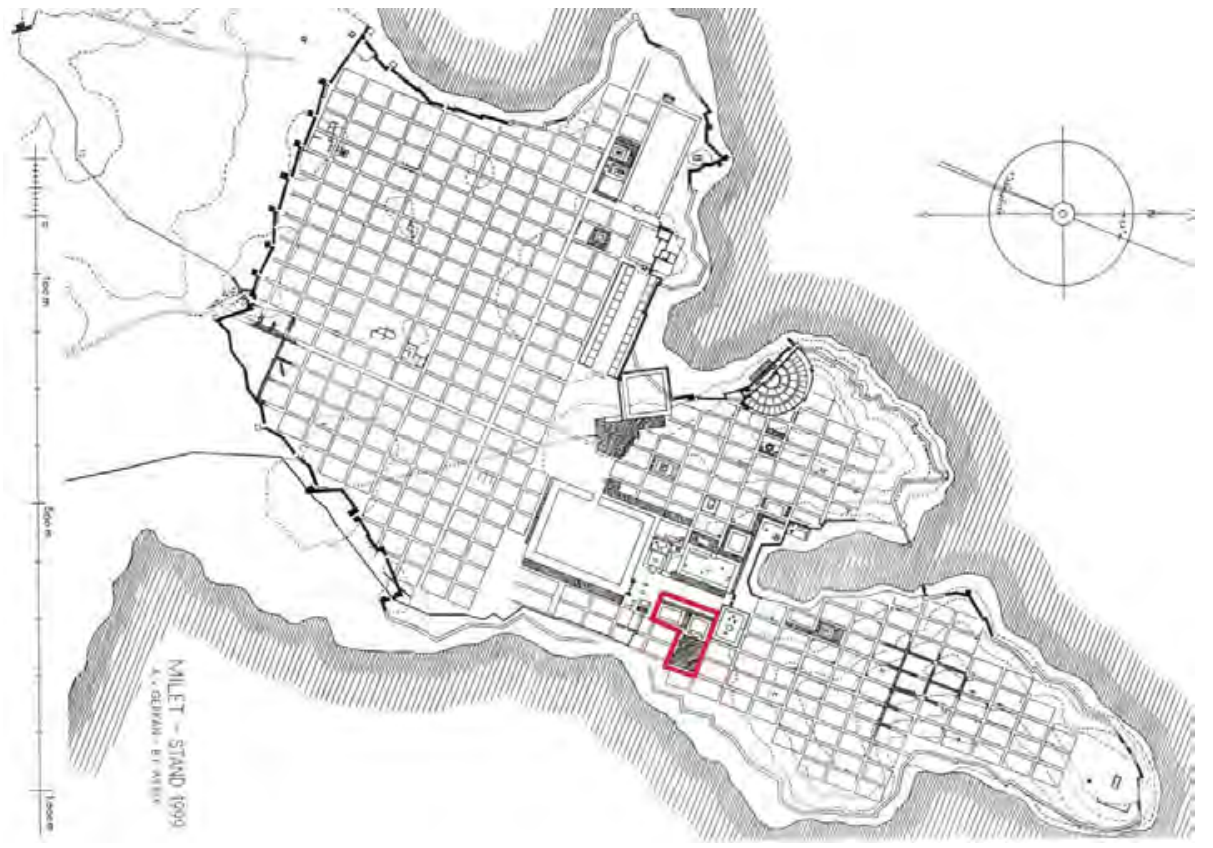

Fig. 2. The plan of the city of Milet highlighting the gymnasium and the palaestra Sursa: http://www.ruhr-uni-bochum.de/milet/in/stadt-plan/stadt-pl.jpg, accesat 17.05.2018, image processed by the author

The philosophical gardens or the public gardens are a response of the democratic regime of the period, which brought a plus to the human society. The walking places and those for leisure, the parks and the pools of the palaestras and gymnasiums are public and very often localized outside the town. Towards the ending of the $4^{\text {th }}$ century BC, we can talk about a step forward in education, but also in the indoor-outdoor relation. Inside these gardens, Plato and 
Aristotle, according to literature, founded the academies. "The Platonic Academy would carry out its work in the gardens of Academism, planted with small osiers, yew trees, and poplars with silver leaves, elms, and balance pans". (Vişoiu, 2001, p. 32)

The orientation towards religion in the Middle Ages is the one which would dominate in education, by offering the primary type of collective education, which would determine the appearance of the educational space. The plan of ancient gymnasium lies at the foundation of school constructions. The inner yard matches perfectly with the secluded spirit which characterises the period. The plan of the Saint-Gall manuscript (Fig. 3) lies as a witness of the monastery school, surrounding the year 818 . The concept is a mixture between the Roman fortress (castrum), rigorously transposed by means of exactness and adjustment and the principle of ancient gymnasium. Nevertheless, although the education space does not have its own yard, one can observe the close attention given to the gardens, those being attentively projected.

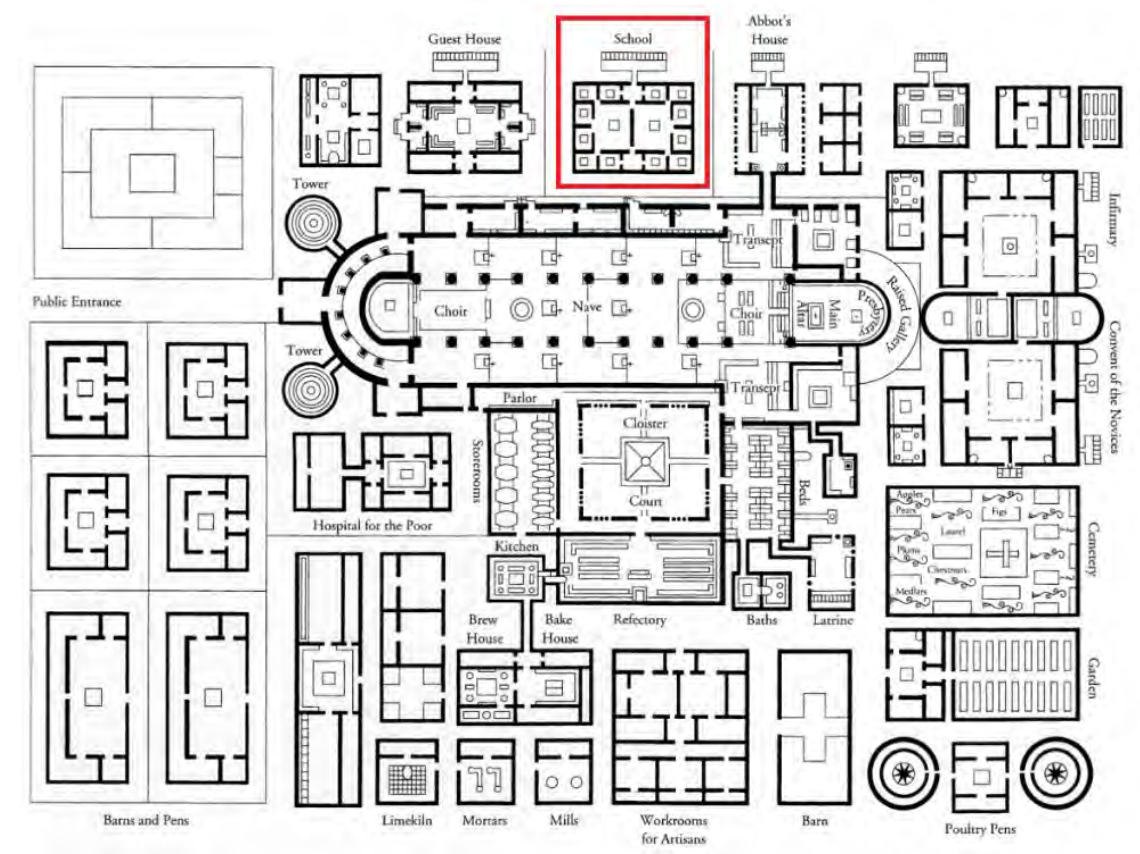

Fig. 3. Plan of the Saint Gall Monastery, Switzerland Sursa: https://classconnection.s3.amazonaws.com/530/flashcards/2210530/png/screen_shot_2012-11-09_ at_112058_am1352486003686.png accesat 17.05.2018, image processed by the author

The type of urban school from this period, usually built inside private houses, is defined by means of a specific element, which is different from the other constructions which are being characterised as isolated, secluded, neutral and distant from nature, thus demonstrating the privileged character of educational spaces. (Vais, 2008, p. 29)

The Renaissance remarks itself through the presence of famous scholars. The Czech A. Comenius (1592-1670), in Didactica magna, describes the importance of a very well thought space as determining for the educational process: "let's prepare school first, in the same way the bird first prepares its nest" (Vais, 2008, p. 29).

Starting with 1545, we can talk about the first botanical garden in Europe, created at Padua, which at first had an educational role, being situated inside the Faculty of Medicine. The garden represents the birth of botany as a science, the birth of scientific progress, but also, at the 
same time, it plays an essential role for the understanding of the relation between the human beings, nature and culture. (UNESCO, 1997)

The growth of the number of pupils inside the schools registered between the $18^{\text {th }}$ and $19^{\text {th }}$ century, stresses the relation between the tutor and the class of pupils. The period remarks itself through the presence of various plans, with a major importance until nowadays, such as: classic academic, compact academic and popular. (Vais, 2008, p. 29) The plans of educational units of classic academic type were characterized by inside yards which, as in the Middle Ages, didn't have an educational function. The compact academic type, used mainly in the second half of the $19^{\text {th }}$ century is based on symmetry, denseness, so that the inner yards would disappear. The Gymnasium of Frankfurt bears witness to that, because it does not show any relation with the exterior space, focusing on the theoretical part of education. Whereas the third plan, the popular one, contains innovations valid until today, from the functional point of view, but still remains neutral to the natural environment.

The 30's generated what is being defined as "hygienical school", known as pre-contemporary school, with specific elements, such as: the lack of rigidity, half-pavilion plans or tentacular plans, classrooms along corridors, and rich architectural program. One example, unrealised, is the Primary School of Bonnames in Frankfurt on Main, projected after the category of tentacular plans. Innovative is the body of classrooms that develops a direct relationship with the green space through outdoor classes. The other housings - the gym and the lobby separate together with an alignment of trees, the leisure yard, green and of big dimensions, capable to host very diverse activities. It is remarkable the lack of any surroundings and a clearly shaped physical barrier, this being done by means of a green curtain, clearly stating the free character of the school.

Corona School-Bell in Los Angeles, 1935, is another example which supports the concept of open schoo (Fig. 4l). Although the project represents an extension of an older school, it contains innovative elements - the classrooms are disposed only at the ground level and they have been conceived so that they would allow their extension towards an outdoor space. This kind of solution assures the development of outdoor classes, offering "the best contact of the child with nature, which is so necessary for his harmonious development" (Vais, 2008, p. 32).

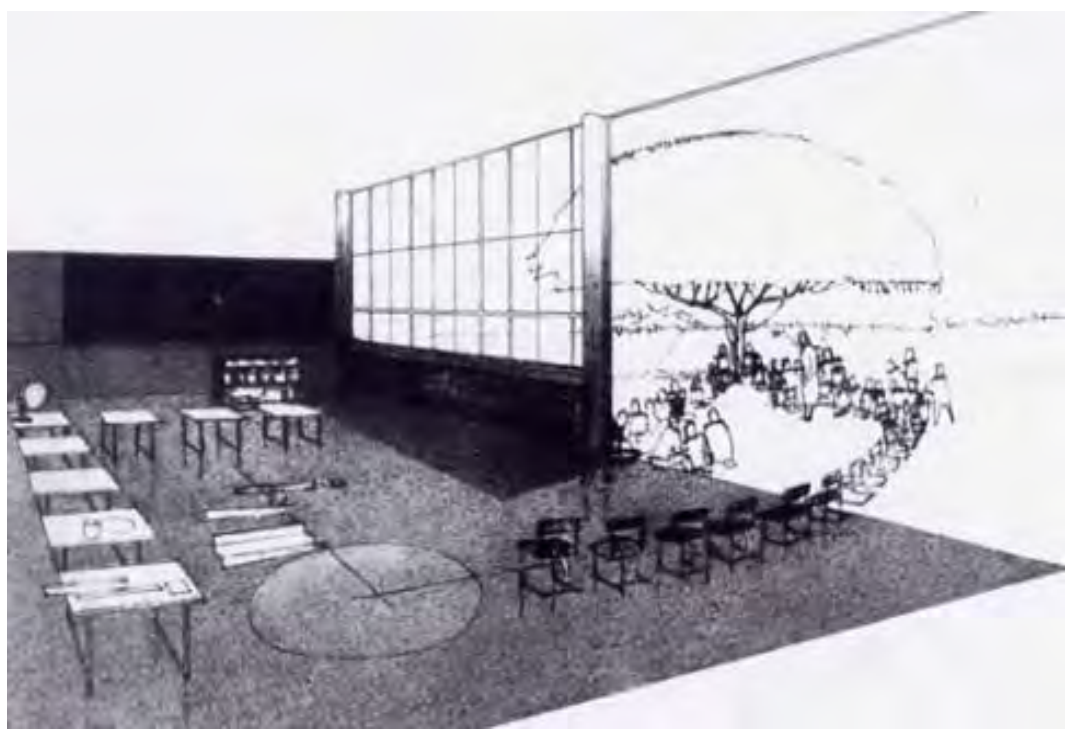

Fig. 4. Image from Corona School-Bell, Los Angeles, 1935- Running outdoor lessons Sursa: http://www.etsavega.net/dibex/imatges/Neutra_3.jpg accesat 19.05.2018, image processed by the author 


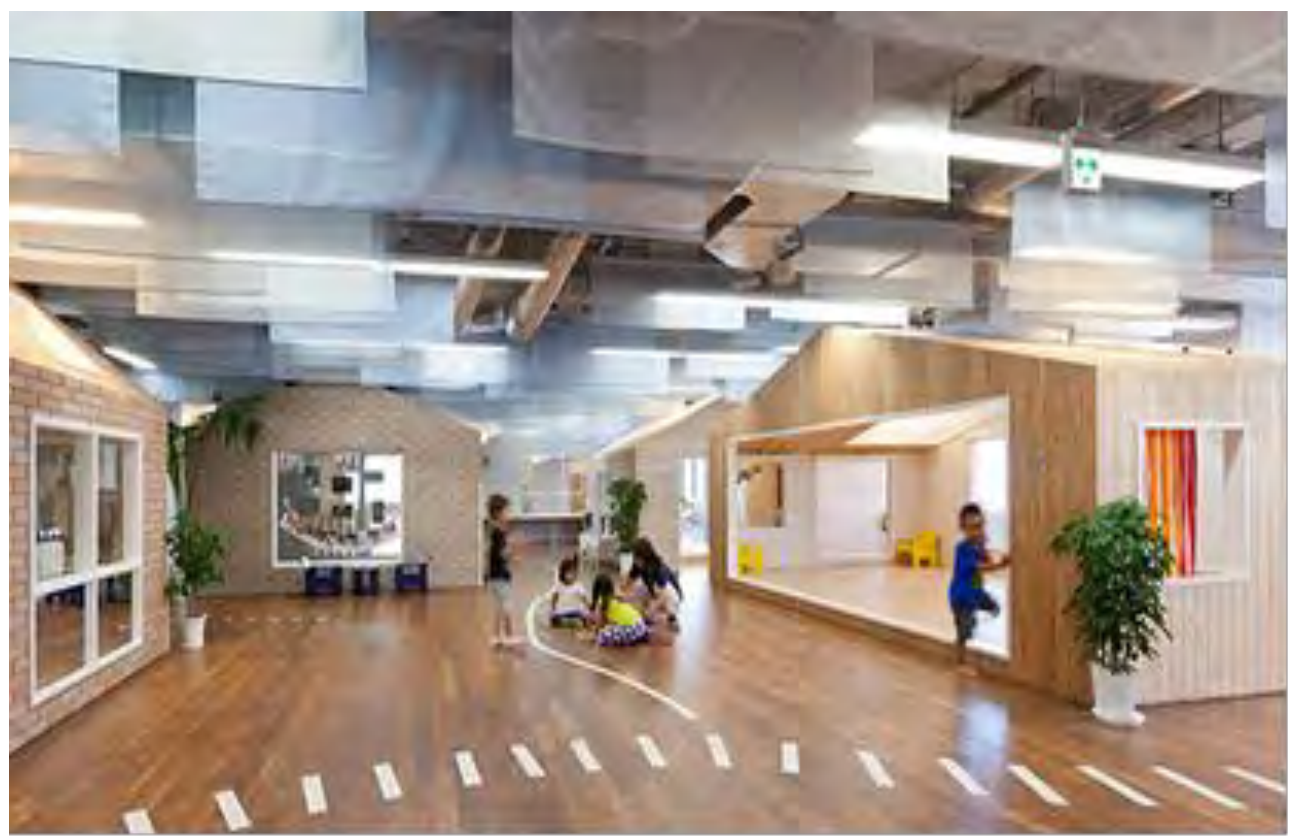

Fig. 5. Hakemiya kindergarten, in Kumamoto

- outdoor space of small dimensions where the lack of facilities can be noticed.

Sursa: http://www.designboom.com/architecture/suppose-design-office-kiddy-shonan-cx-nursery-school/, accesat 19.05.2018, image processed by the author

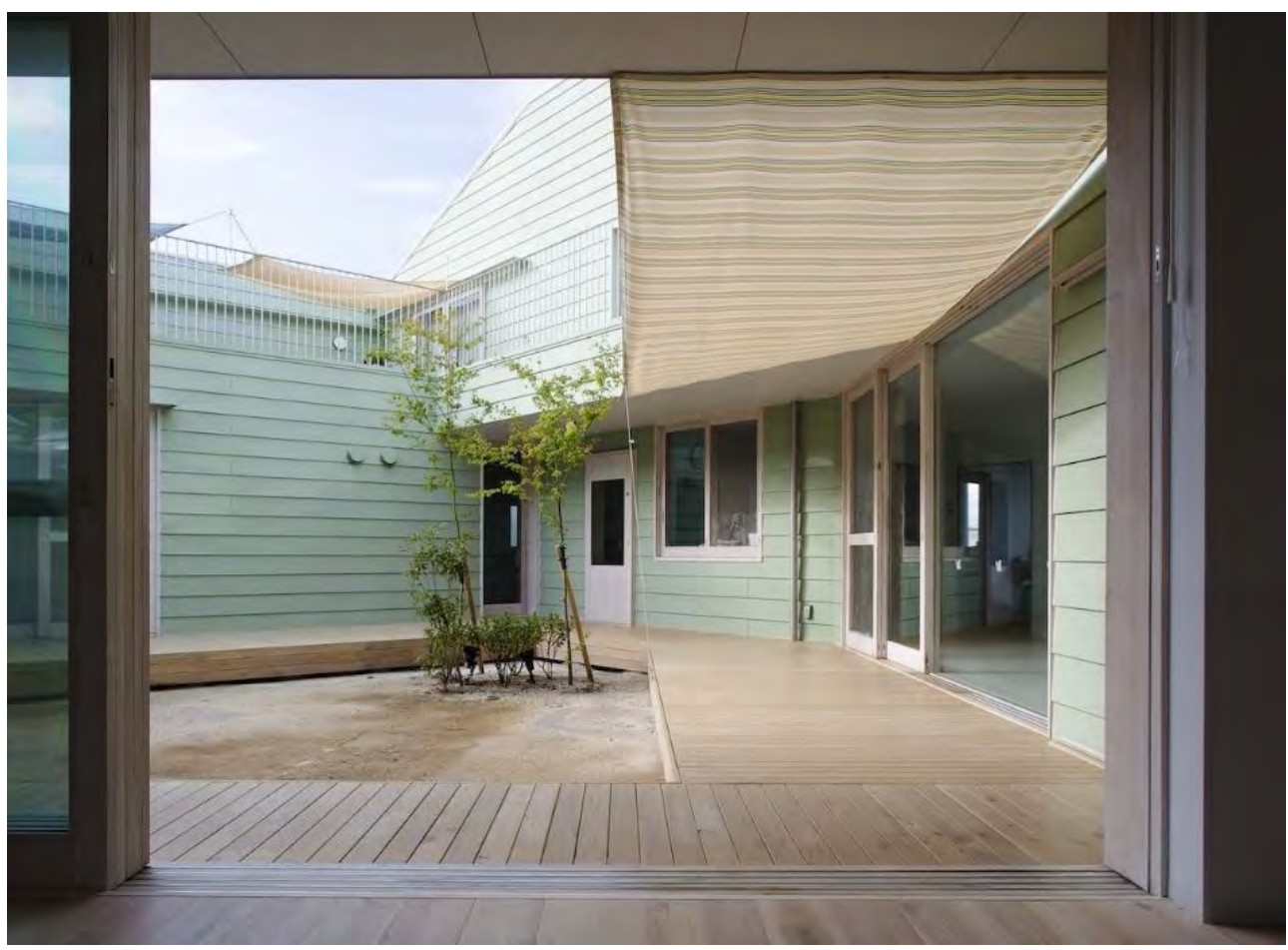

Fig. 6. Kiddy Shonon Kindergarten, in Kanagawa.

In designing the school unit, Suppose Design Office did not integrate any outdoor space. Source: http://www.archdaily.com/592547/hakemiya-nursery-school-rhythmdesign-case-real/, accesat 19.05.2018, image processed by the author

Nowadays one can remark two tendencies in designing the educational units. The urban overcrowding, together with the necessity of a decent education, determine the school to be in lack of outdoor spaces destined for leisure. These types of situations of compromise sometimes lead to the appearance of green spaces situated on the roof, but these fail to satisfy 
the children's needs and those of the teenagers to understand the natural environment. Japan is without doubt a source of this kind of examples, such as Kiddy Shonon kindergarten in Kanagawa, projected by Suppose Design Office, which does not have any relation with the exterior, all the activities being run inside (Fig. 5). The exterior arrangements at a bigger or smaller scale are subject to the second tendency. For instance, Hakemiya kindergarten in Kumamoto, realised by Rhythmdesign and CASE-REAL, is provided with an exterior space of an inner-yard type, of too small dimensions, with poor facilities, the most remarkable thing being the presence of a lonely tree (Fig. 6).

\section{The benefits of oudoor education}

„We are not saying good-bye to our classrooms; we are opening them up"

Simon Beames, Lecturer at the University of Edinburgh

The education process which takes place outdoor implies the engagement of children and youngsters in different activities. The teachers should act as facilitators, using multi-sensorial and experimental approaches, so that the little ones would be encouraged to involve in emotional, physical, spiritual and cognitive experiences, as part of the learning process.

The place in which people engage in the process of accumulating knowledge helps them make connections between their experiences and the world around them, in a significant environment. The thematic arrangements, especially the ones destined for children, offer a diversity of resources and spaces difficult to reproduce in an indoor environment. Each type of experience with an educational feature, developed outdoors, should complete another one and form together a progressive and coherent range of experiences for children and teeanagers.

There is a substantial base of national and international proofs regarding the benefits of outdoor education in the natural environment (Scotland, 2007, p. 7). Their impact on children and teenagers is firstly connected to wealth and welfare, personal development, personality, and education.

There is a substantial base of national and international proofs regarding the benefits of outdoor education in the natural environment (Scotland, 2007, p. 7). Their impact on children and teenagers is firstly connected to wealth and welfare, personal development, personality, and education.

There are general benefits of learning outdoors, and these are:

- the connections with the real world outside the classroom are experimentally realised, thus contributing to the development of skills, knowledge and understanding in a significant context;

- the outside environment acts as a stimulus for creativity and enhances the learning process. This brings opportunities connected to challenge, inquiry, critical thinking and leisure;

- the pupils reach to the conclusion that not everything that surrounds them matches with the models or the course books. This doesn't mean that what they discovered is "wrong". Instead, it is developed the degree of awareness of the complexity of the real world and this can contribute to the development of critical thinking abilities; 
- the children and the teenagers are capable to understand the relevance of a subject taught in school reported to the day-to-day life and the surrounding environment;

- the students can sometimes behave differently outdoors. The quiet students can talk more, and others can become calmer and more focused, being influenced by the exterior, and especially by the natural and green environment;

- the multi sensorial experience outdoors helps the efficient memorising the knowledge;

- learning in an environment less structured can offer a different education experience, which is different from that in the classroom;

- the learning experience becomes more relaxed for many pupils.

\section{Considerations for designing the leisure spaces attached to the educational units}

Many types of leisure activities can take place spontaneously in spaces which do not require special arrangements (inside a private place or in public spaces - the street, the park, the market etc.), but some components of the loisir such as culture or sport are often conditioned by specific thematic spaces and arrangements. For instance, the show rooms, reading rooms or multimedia rooms require the necessity for a very well thought exterior space, this being transformed, in some situations, in settings for cultural activities, while some games can be practiced only on playgrounds of standard dimensions, and the assistance to this kind of events implies the presence of typical facilities - arrangements of a gradena type. These spaces destined for relaxation are "generated and generating social behavior" (Chira, 1998, p. 22), so it is necessary, from the beginning, a study of the settlement of loisir facilities according to the social and geographic context for an analysis of the necessity of the function and its impact over the intervention area. The reliability and the flexibility of the spaces also represent an important aspect in order to assure a continuous exploitation and the necessary adaptability for a good functioning of the object on a long term.

The following four principles, such as the quantity, the quality, the good practices and the vision are relevant aspects for planning and delivering the relaxation outdoor facilities:

a) The quantity: the exterior arrangements, relaxation and sport spaces should be delivered in order to satisfy the request of the most popular activities, "basic" ones, within each planning district;

b) The quality: relaxation facilities and outdoor, open and delivered spaces should be of a high quality, and here we can talk about appliances, exterior aspect and design. These are necessary in order to satisfy the needs and requirements of the users;

c) Good practices: by means of an easy access, it should be encouraged the best usage and complementary improvements should be allowed. Also, it should be delivered integrated relaxation environments and an open green setting which should define a pedestrian character to the area. For this objective to be achieved, it could be necessary, in some situations, to overcome the lowest established limits for the delivery standards. The setting, as well as the individual components, should be revised periodically to consider any possible modifications according to the needs of the users.

d) Vision: in implementing an attractive relaxation area, one should consider the emplacement features, the structure of the population and the socio-economic context, as well as the time dedicated for rest. When the project is addressed to a certain age 
category, especially children and teeagers, the flexibility of the usage is essential. These spaces should integrate more and more diverse features in order to attract the focus group, to allow the practice of "extreme" sports, by means of special appliances. We should also pay attention and take into consideration the delivery and the accessibility of facilities for special groups, such as the persons with disabilities.

\section{The outside environment through the eyes of a child}

Jean Piaget and Bärbel Inhelder (1956), well-known for their epistemological studies on childen and the cognitive theory, claim in their work "The child's perception over space" that the children's development is the result of the interaction between the social and the natural environment. Also, they state that from birth until the age of 18 , the child passes from an egocentric thought, based on reflexes and a general behaviour model, to logic, abstract and symbolic thought.

From Proust we learn that the presence of nature in a child's education is essential and, moreover, the fact that the love for nature is formed from childhood and it is maintained for the whole life. A child's abilities to become emotionally attached to a place are due to the capacity of a space to become special, to offer comfort and moreover to arize joy and amazement. We can state that a space can bring safety in such an unstable world, especially from a cultural and social point of view, and that the small hidings are stable and cannot disappoint, they being worth of a child's love, even after he has become an adult. (Cele, 2006, p. 14)

The way in which the children transform the neuter places in real temples of play, so special and sometimes "secret", lies in simple gestures, such as the moving of some sticks or the building of a small hump of stones. These handlings of vegetation and ground are often so small that only a child can perceive them to their real value. The landscape and the natural environment influence the children's behaviour, their play and especially their education, these being the main actors alive in the life of a healthy child. There are also remarkable the child's sense of property and the need of the teenagers to transform the place which is strictly connected to this feeling and especially to the feeling of being "home", which afterwards he can further pass on.

Different studies elaborated in Sweden and England (Cele, 2006, p. 12) show the way in which the experiences of a child over the space are multidimensional, formed not only by the concrete process - senses, but also by the abstract one - emotions. The interactive learning methods are placed in the playing environment, the outdoor space, which allows the children to benefit from a direct experience, whereas the educational act is running in the subconscious through movement, play or simply relaxation.

The flora, the green of the environment has the role to awake a variety of stimuli and moreover has the capacity to make us forget of time and space and to focus more on the current activity than of the past or future one. Its necessity becomes more acute in the urban environments. Nabham and Trimble speak in 1994 about the children's situation in the urban environment especially about the new abilities that should be developed, as the one of "travelling beyond the pavement in order to have access to vegetation and earth, which allow them to climb and even fall" (Nabham; Trimble, 1994, p. 24). We can therefore speak about the way in which teenagers emotionally engage with nature when they play in the middle of it, learn from it, starting therefore to shape a protective behaviour. Sometimes we forget about the joy we used 
to feel when we used to climb in a tree, often in the search of fruit that weren't even ripe, and suddenly became cautious. The outdoor facilities destined for children and teeangers are based on the feeling of protection, therefore they are not challenging and do not have the capacity to develop coordination, flexibility, and focus.

We can state that a child's perception over the environment is totally different than the one of an adult. The children live in a different world than the one of the adults, a much lively world. Nevertheless, the reality of the small ones is strongly anchored in the word of the adults so we can also discuss, at the same time, of a social alienation when it comes about the projection of the spaces destined for pupils. For this reason, recent researches, with or about children, are more and more taken into consideration in vast areas such as: architecture, landscape architecture, sociology, pedagogy etc.

Nevertheless, the challenges of the new designing methods don't appear from the understanding of the fact that from a certain degree the children feel and perceive the environment differently than the adults; the main problem lies in the understanding of these differences and the possibility to eliminate them through mutual understanding bridges. This aspect is determining when we analyse and project outdoor spaces for the educational units. These areas are destined, nevertheless, for simultaneously serving not only children, but also adolescents, as well as teachers; let's not forget that the breaks are for all involved in the educational process.

\section{An interview taken with an architect, sociologist, and educator - personal experience}

\section{About Frode Svane}

I made acquaintances with Frode Svane on one of the biggest social-media platforms, Facebook, during my research within the doctoral studies. He was born in Norway and recommends himself as an architect, landscape architect, educator, and sociologist. He also adds that he has an experience of over 40 years and therefore this "atypical mixture of knowledge and experiences" forced him to develop a deep interest in getting the users involved in the creation process.

Being an educator offers him a close, special relationship with teenagers and this can be observed in the majority of his works addressed to the young ones and he also acknowledges that he uses schools for research and implementation of projects: "I often use schools as a base for the development process, so that the children and teenagers would have the best opportunity to learn about the environment and change it".

\section{"Participation and involvement create commitment and responsibility"}

When asked about his opinion on the role of the active participation of "urban" children within the natural environment, the architect answers clearly and concisely: "I don't think this aspect should be explained because it is very easy to be understood: participation, involvement and the contribution of each one is even more important for children and teenagers who grow in big urban areas, regardless they live in the centre or in a suburb". Therefore, the society must be capable to accept the participation and the teenagers' involvement as citizens with thoughts and visions. Their contribution can bring real changes in the neighbourhood or even in the local 
society and transform itself in a particularly important background when they will reach another age category.

During the interview, Frode Svane talked about architecture and nature together with the nature's role in education: "The most efficient way of making a child or a teenager aware of the surrounding architecture and the greatness of the environment is by giving him the opportunity, during the growing period, to participate in the space creation process, independently if it consists in buildings or green spaces. The opportunity to get involved in the changing and making new places or simply improving the already existing ones must be given in the children's space: the school."

Also, another important aspect in involving children teenagers in these kinds of projects, as we discussed in the theoretical part, lies in the idea of "membership". It is a feeling that the children are extremely fond of, because, without being aware, it generates responsibility towards a place. Frode Svane was a chief architect in the city of Lørenskog for 4 years and, according to him, has made out of this experience a mission for a more decent learning. He implemented a project called "Growing up in Lørenskog" - the first among of a long series of projects which aim towards the active participation of children and teenagers in the process of planning the usage of municipal areas. He remembers how, during a school project, the children developed "a property sense, different from the one of an adult - it is our place which WE take CARE of!"

We all know that from the moment we manage to draw the attention of a child towards a thing he develops a special passion for it, making a mission out of it, until he gets bored. Frode agrees with this and says that working with teenagers should be made of "special sessions of half an hour as being sufficient to arouse interest and to create the wish for future participations".

In time, the architect observed a pattern and considers that an organized participation may lead to: 1 . Responsibility - the active participants take better care of the environment; 2 . Strong affiliation with the place; 3. Involvement; 4 . Identity - the place reflects the needs of the community; 5 . Cohesion - strengthens the social contact regardless the age, sex or culture; 6 . Abilities related to team work; 7. It disappears the tendency towards making damages; 8 . The tendency towards violence and conflict are remarkably softening.

\section{The importance of nature in shaping the teenager's personality and the importance of people in shaping nature}

We have seen form the previous studies that education is strongly connected to a healthy mind lying in a healthy body. Nature has its role through direct participation in the formation of personalities and self-esteem and, further on, this type of education marks the environment.

Norwegians have a special connection with nature, and this can be observed in the respect they showed during time towards the forests. Frode Svane himself stated in one of his interviews about "Playground in Norwegian forests" project: "Norwegians developed a tight relationship with the local forest or the nature from early ages. In this country people used to live in the middle of nature and we realized that we are born with the feeling of protection and caring for the green space and believe that a natural environment with educational features is useful for all people." (Nakamura, 2003, p. 15)

The easiest way to arouse this feeling is through the outside spaces, regardless of being educational or not, but connected to the school. The nearest exterior space close to education 
units is the place in which children from the whole world must spend most of the time, with or without their asking for it. The transformation of these green spaces is therefore necessary, and it is based on the real needs of the children. The dialogue between interior and exterior should be honest and built according to deepened knowledge regarding the way in which children really learn. The exterior should produce enthusiasm to the users: "it is the glue which speeds up the knowledge assimilation by the body!" (Frode Svane, interview given on May 5 , 2018).

\section{Learning through play - study case}

During the last two millenniums, China was a civilization with an aristocratic social structure. The state learning system is considered, also by the rest of the world, to be a rigurous and traditional one, with an education strongly influenced by the phylosophy of one-side transmition of knowledge, from generation to generation. In the era of economic prosperity and globalization, the course of the education process suffered modifications, being dramatically changed. The pupils are allowed the right to venture themselves in the broad universe of knowledge, to open for themselves new horizons through the development of their own personality and wisdom, as well as through the capacity to form a critical thinking.

The ones from Gravity Green were inspired by this trend when designing the campus destined for the Yi Zhong De Sheng high school in the south of China, in which the pupils are encouraged to interact with the landscape by means of educational and thematic arrangements, and therefore to look for knowledge in a proactive way. The project, finalised in 2010 is spread on a surface of 12,500 square metres and supports over 2800 pupils with different school programmes for which the outdoor environment doesn't remain neuter (Fig. 7).

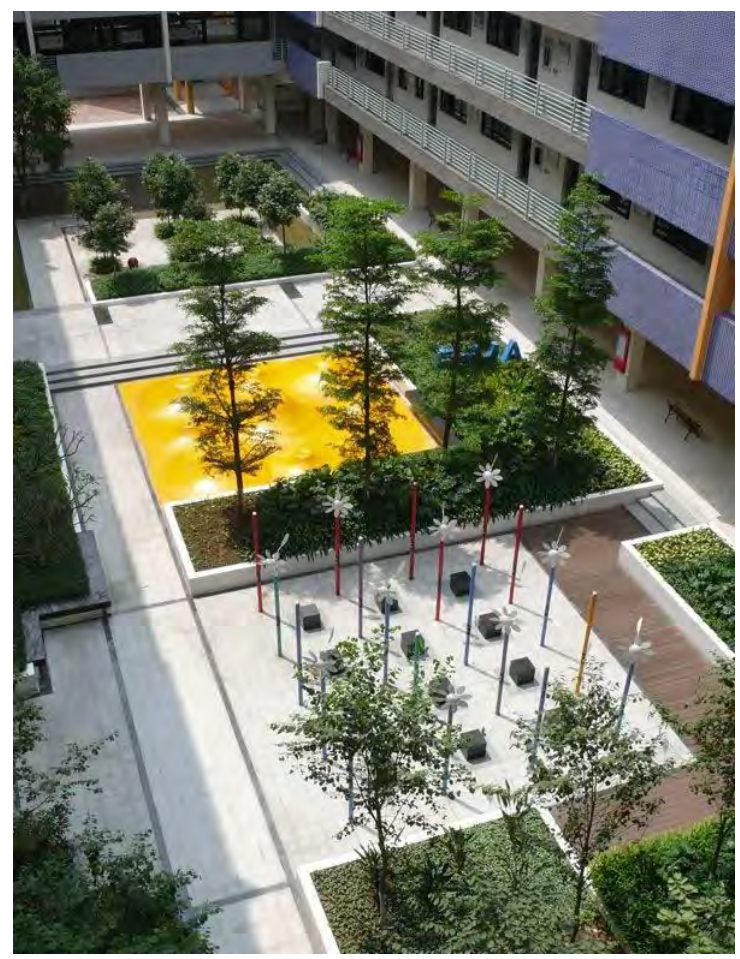

Fig. 7. IGeneral view of Yi Zhong De Sheng High- School project from south China, Gravity Green Sursa: http://www.gravitygreen.com /works /institutional\#yi -zhong- de- sheng- secondary-school, accessed 17.05.2018, image processed by the author 
The campus is developed after the "finger" type plan, being formed from a series of four multifloored blocks destined for the educational process. The buildings form a number of outside spaces between them, protected on all sides, a fact which offered the architects the opportunity to transform the natural environment in a vibrant educational environment and through specific elements they revitalised the architectural union.

The atrium type yards are relevant for three academic disciplines: physics, art and geography, therefore it is a well-defined subject which reflects the educational activity from the elements which surrounds it. Out of these large areas specific topics derived such as: The Universal Law, symbolically called Sir Isaac Newton, The Law of energy preservation, The Kinetic Energy Hill, and Wind-Engines Farm (Fig. 8), the third one being the Demography (Fig. 9). All the facilities contain active-educational settings, ingeniously transposed in a playful environment. These spaces are not only outside arrangements destined for relaxation, but also outdoor classrooms, fitted with sculptural elements, diverse colours and visual stimulation appliances, capable to stimulate the pupil's curiosity, to maintain their interest and to release their desire to touch, interact, examine, experiment, and, in the end, to consolidate their fundamental knowledge.

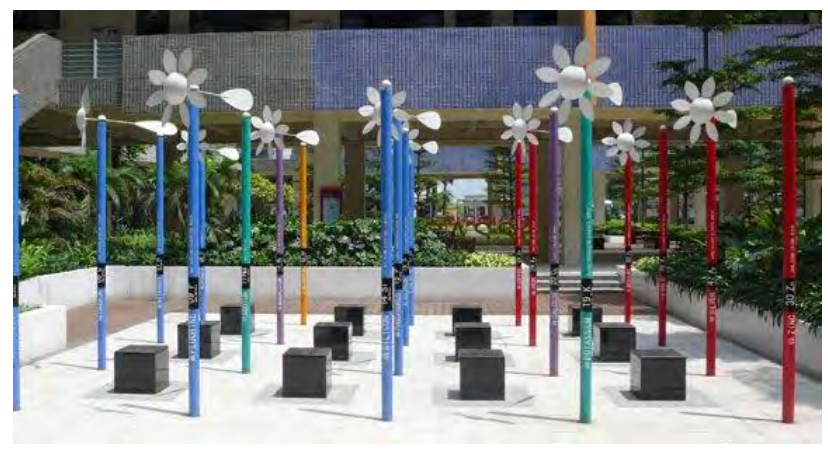

Fig. 7. Picture of Windmills Garden Sursa: http://www.gravitygreen.com /works/institutional\#yi- zhongde- sheng- secondary-school, accessed 17.05.2018, image processed by the author

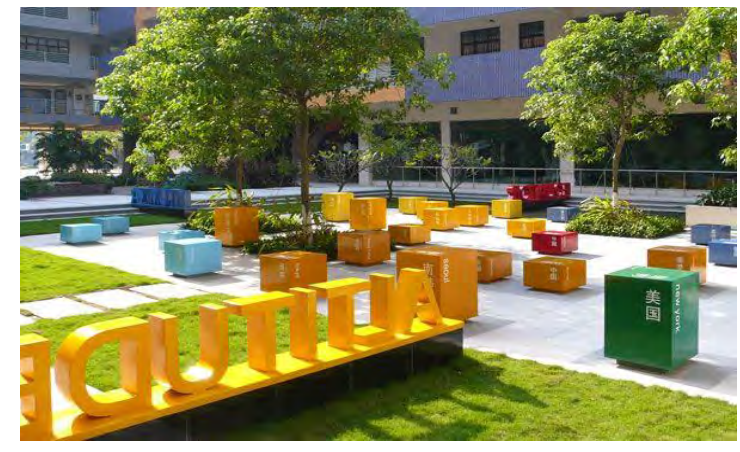

Fig. 9. Picture of Geography Garden Sursa: http://www.gravitygreen.com /works /institutional\#yizhong- de- sheng- secondary-school, accessed 17.05.2018, image processed by the author

The tendency to create spaces destined for direct interaction also is not ignored. The architects's intentions can be passed through the theoretical filter, especially from the point of view of how children perceive the space. The ones from Gravity Green managed, by means of thematic arrangements with an educational role to create multi-sensorial spaces which satisfy the children's need to know, socialize and also to assimilate information unconsciously. Different studies made in Sweden and England (Cele, 2006, p. 12) show the way in which interactive educational methods placed in the play environment and the outdoor space allow the children to benefit from a direct experience, and the educational act is internalized by means of movement, play or merely relaxation.

The importance of play in learning and the development from childhood to maturity is vital in each life stage and different from the point of view of shapes, styles and implications. The children respond positively when the information is delivered in a cheerful space, in a nonacademic environment or professional one. In other words, learning should be an interactive cycle, a virtuous one, in which the children actively participate through observation, integration, exploration, intuition, application and through processes of human behaviour stimulated by the natural environment. 
A learning-through-playing space opens new possibilities for humans by means of giving them the possibility to become self-motivated and to define themselves as well as to learn guided by their own curiosity and desire. This project is an example of organization of the exterior space which integrates elements from the most diverse fields (architecture, physics, and geography) into landscape architecture, as well as the positive impact of a design intelligently integrated.

\section{Conclusions}

In the first part of the study it has been demonstrated that, across time, the spaces destined for exterior activities within the educational units have played an important role in the functional organization of the institutions, subsequently acquiring aesthetic values. We have also established that the relation between inside and outside space is determined by the tendencies of a certain epoch. Each civilization marks the evolution of the educational system, but also the space destined for the learning process. If from the Greeks we could collect for the first time the advantages of an open space education, the Middle Ages made us aware of the privileged character of school within the society. The innovations carried out over the green spaces can be observed no sooner than 1930 when more and more projects, finalized or not, showed flexibility, free spirit, and creativity. Therefore, we can speak of landscape arrangements which rely on the natural and green setting in order to pass on data in the children' subconscious, thus arousing interest towards nature, forming the ability to focus, and last but least, the ability to learn.

The second part of the paper starts from the modern children's tendency to stay as much as possible inside the house because where "there are all the electronics and games" (Louv, 2005, p. 9). The challenge is how we manage that through arrangements to arouse the teenagers' interest so that they would spend more time in the middle of the outside world, far away from the monitors. Research fields within geography, architecture, landscape architecture or sociology are only a few which question this matter and try to elaborate studies in order to think out efficient and feasible solutions. In my opinion, a first step are the activities within schools, as well as outside thematic and educational arrangements. The children have to spend a significant part of their life within those educational units, whereas a good quality education is based, firstly, on physical and mental health.

The outside environment looks totally different through the eyes of a child, although his reality is strongly anchored in the activities of adults. Just as Proust stated, the love for nature is born during childhood and it is so pure that it persists until adulthood. We observe that teenagers engage socially, intellectually, and especially emotionally with nature when they are playing in the middle of it, learn from it, and therefore starting to develop a preservation behaviour.

Another way to attract children and teenagers in the natural environment is tightly connected to the feeling of property and "home". The way in which they manage to get themselves attached to a place is made of simple things, and their interventions in the outside space, although small, make a difference. At this point it appears a problem related to the ego of the professionals, who, being blinded of rules and procedures have the tendency to label the space by applying a theoretical filter, without asking themselves about the functionality of the outside space and the sensitiveness of such a space. The children's ability to influence and participate to this type of projects depends on the will of adults to listen, but also on the way in which their wishes and suggestions are interpreted and taken into consideration. 
We know that a child sincerely becomes attached to a thing and turns it into a real mission if it is especially important to him and does not back away until he gets bored of it. If we manage to understand that nature plays an important role in the development of children and teenagers and that their way of perceiving the natural environment is different than the one of an adult, together with the need to directly involve children, we can define a few golden rules in designing spaces.

Through the direct participation of children and by offering them the possibility to leave their personal mark in the outside space connected to the school building, we can manage to develop their instinctive care for the preservation and protection of nature. As stated previously, the children need to feel that the place belongs to them, and for this goal to be achieved the feeling of property has to be subtly created, so that the space would become attractive, without it being imposed.

\section{References}

Cele, S., 2006. Communicating Place - Methods for Understanding Children's Experience of Place, Stockholm: Departamentul de Geografie, Universitatea din Stockholm;

Chira, M., 1998. Direcţii de dezvoltare a centrelor destinate sporturilor de recreere, Bucureşti: s.n.; Gravity, 2009. yi zhong de sheng secondary school.

Accesat 14.0.20158: http://www.gravitygreen.com/works/institutional\#yi-zhong-de-sheng-secondaryschool;

Iliescu, A.-F., 2003. Arhitectura Peisageră. Bucureşti: Ceres;

Nabham şi Trimble, 1994. The Geography of Childhood. Why children need wild places. Boston:

Beacon Press;

Nakamura, A., 2003. Landscape design in Scandinavia:

http://happa88.life.coocan.jp/landscape_design_in_scandinavia.pdf

Piaget, J. și Inhelder, B., 1956. The Child's Conception of Space. Londra: Routledge\&K.Paul;

UNESCO, 1997. Botanical Garden (Orto Botanico), Padua.

Accesat la 14.05.2018: http://whc.unesco.org/en/list/824.

Scotland, E., 2007. Taking Learning Outdoors: Partnerships for Excellence. Glasgow: Deputy Education and Young People Minister;

Vais, G., 2008. Programe de Arhitectură. Cluj-Napoca: U.T.Press;

Vişoiu, D., 2001. Istoria grădinilor şi parcurilor. Timişoara: Mirton; 